\title{
Recent Advances in Cellulose Nanofibers Preparation through Energy-Efficient Approaches: A Review
}

\author{
Seyed Rahman Djafari Petroudy ${ }^{1,2, *} \mathbb{C}$, Bruno Chabot ${ }^{1}{ }^{1}$, Eric Loranger ${ }^{1}$, Maryam Naebe ${ }^{3}{ }^{(1)}$, \\ Jamileh Shojaeiarani ${ }^{4}$, Samira Gharehkhani ${ }^{5, *}$, Behzad Ahvazi ${ }^{6}$, Jinguang $\mathrm{Hu}^{7}{ }^{7}$ and Sabu Thomas ${ }^{8}$ \\ 1 I2E3-Innovations Institute in Eco-Materials, Eco-Products, and Eco-Energies Biomass Based, \\ University of Québec at Trois-Rivières (UQTR), Trois-Rivières, QC G8Z 4M3, Canada; \\ Bruno.Chabot@uqtr.ca (B.C.); Eric.Loranger1@uqtr.ca (E.L.) \\ 2 Cellulose Nanotechnology and Carbohydrate Chemistry Lab, New Technologies Faculty, \\ Shahid Beheshti University, Tehran 1983969411, Iran \\ 3 Institute for Frontier Materials (IFM), Deakin University, Geelong, VIC 3216, Australia; \\ maryam.naebe@deakin.edu.au \\ 4 Department of Mechanical Engineering, Western New England University, Springfield, MA 01119, USA; \\ jamileh.shojaeiarani@wne.edu \\ 5 Department of Mechanical Engineering Faculty of Engineering, Lakehead University, 955 Oliver Road, \\ Thunder Bay, ON P7B 5E, Canada \\ 6 Donadeo Innovation Centre for Engineering, Department of Mechanical Engineering, \\ University of Alberta, Edmonton, AB T6G 1H9, Canada; ahvazi@ualberta.ca \\ 7 Biorefining \& Photo-Bioprocessing Research Lab, Department of Chemical and Petroleum Engineering, \\ University of Calgary, Calgary, AB T2L 1Y1, Canada; jinguang.hu@ucalgary.ca \\ 8 International and Inter University Centre for Nanoscience and Nanotechnology, School of Chemical Sciences, \\ Mahatma Gandhi University, Priyadarshini Hills, Kottayam, Kerala 686560, India; sabuthomas@mgu.ca.in \\ Citation: Djafari Petroudy, S.R.; \\ * Correspondence: seyedrahman.djafaripetroudy@uqtr.ca (S.R.D.P.); samira.gharehkhani@ubc.ca (S.G.)
} Chabot, B.; Loranger, E.; Naebe, M.; Shojaeiarani, J.; Gharehkhani, S.; Ahvazi, B.; Hu, J.; Thomas, S. Recent Advances in Cellulose Nanofibers Preparation through Energy-Efficient Approaches: A Review. Energies 2021, 14, 6792. https://doi.org/10.3390/ en14206792

Academic Editor: Adam Revesz

Received: 17 September 2021

Accepted: 13 October 2021

Published: 18 October 2021

Publisher's Note: MDPI stays neutral with regard to jurisdictional claims in published maps and institutional affiliations.

Copyright: () 2021 by the authors. Licensee MDPI, Basel, Switzerland. This article is an open access article distributed under the terms and conditions of the Creative Commons Attribution (CC BY) license (https:// creativecommons.org/licenses/by/ $4.0 /)$.

\begin{abstract}
Cellulose nanofibers (CNFs) and their applications have recently gained significant attention due to the attractive and unique combination of their properties including excellent mechanical properties, surface chemistry, biocompatibility, and most importantly, their abundance from sustainable and renewable resources. Although there are some commercial production plants, mostly in developed countries, the optimum CNF production is still restricted due to the expensive initial investment, high mechanical energy demand, and high relevant production cost. This paper discusses the development of the current trend and most applied methods to introduce energyefficient approaches for the preparation of CNFs. The production of cost-effective CNFs represents a critical step for introducing bio-based materials to industrial markets and provides a platform for the development of novel high value applications. The key factor remains within the process and feedstock optimization of the production conditions to achieve high yields and quality with consistent production aimed at cost effective CNFs from different feedstock.
\end{abstract}

Keywords: cellulose nanofibers; energy-efficient; mechanical process; pretreatments

\section{Introduction}

The use of natural renewable polymers has steadily gained a strong interest over the last three decades and remains as one of the challenges of the 21st century. Cellulose is the most important naturally abundant organic biopolymer in the biosphere and also allocates $1.5 \times 1012$ tons of the total annual biomass production [1,2]. Cellulose is odorless, has no taste, is hydrophilic, and is insoluble in most solvents including strong alkalis at room temperature. By treating cellulose with concentrated acids known as acid hydrolysis, the amorphous regions can be broken up, thereby producing nano-sized cellulosebased crystals called nanocrystalline cellulose (NCC) or cellulose nanocrystals (CNCs) [3] $\mathrm{CNCs}$ are elongated rigid rod-like or whisker shaped particles with a rectangular cross section. CNCs can be prepared from any cellulose source material including wood pulp, 
recycled paper, and paperboard, but is not limited to cotton fibers, hemp, flax, bamboo, sugarcane bagasse, and other agro-biomass [4]. Hence, cellulose-based nanomaterials can be extracted from cellulose fibers using physical, enzymatic, and/or chemical treatments [5]. CNFs are materials composed of nanosized cellulose fibrils with a high aspect ratio (lengthto-width ratio). Typically, the diameters and lengths are $5-100 \mathrm{~nm}$ and several micrometers, respectively [2]. It is a flexible material with crystalline and amorphous regions. CNFs can be produced by a mechanical procedure with or without pre-treatment. The most commonly used approaches to isolate CNF are enzymatic treatment and TEMPO oxidation, followed by mechanical defibrillation. The final product after the delamination process is a gel-like CNF dispersion in water. CNFs have spaghetti-like morphology with typical dimensions of $20-50 \mathrm{~nm}$ in width and up to several microns in length (Figure 1).
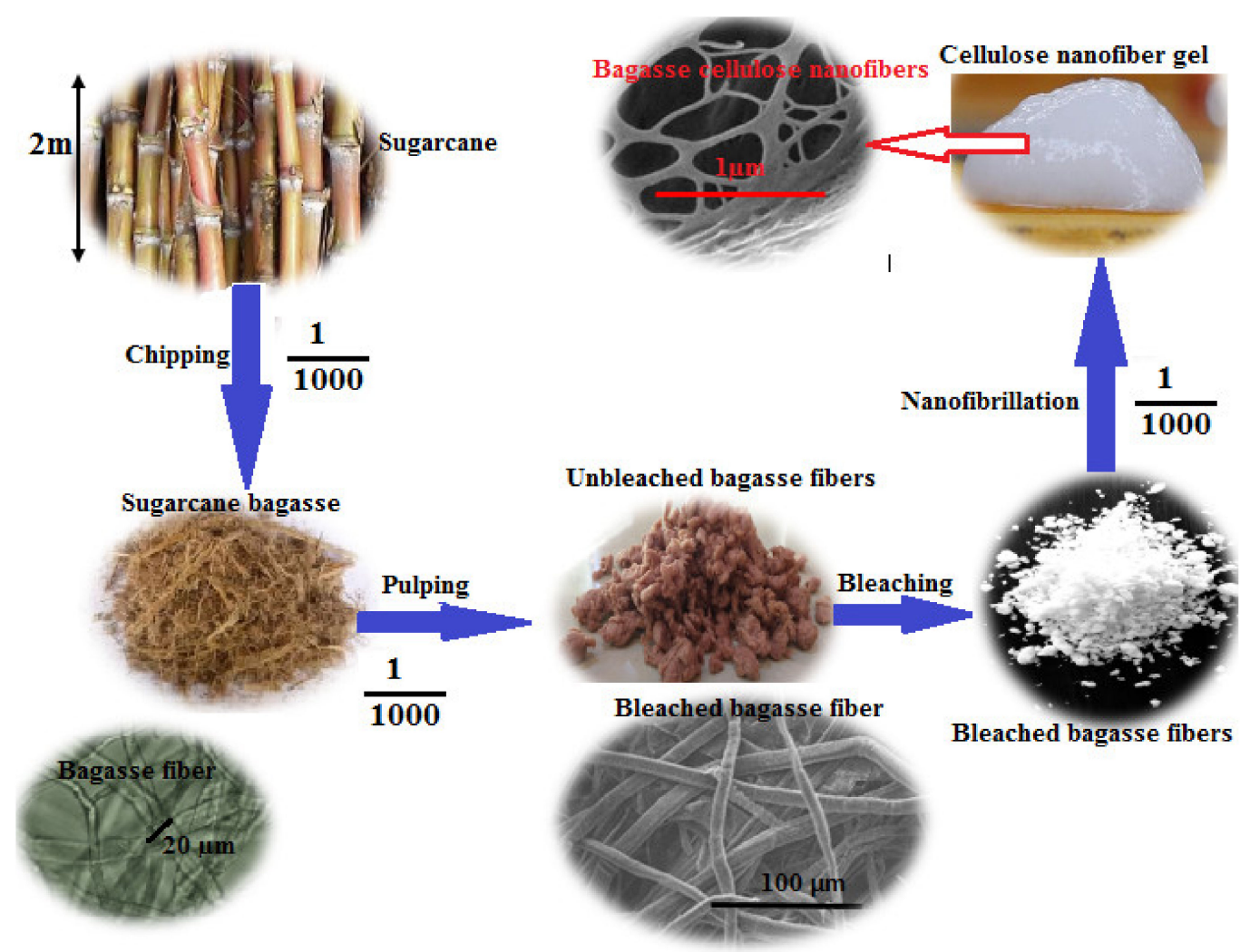

Figure 1. Top-down approach for preparation of cellulose nanofibers (CNFs) from bagasse.

CNFs are categorized as one of the most promising and emerging bionanomaterials for advanced high-performance bio-nano composite applications [6]. Its discovery has appended exciting innovation into natural plant fiber-reinforced polymer composites [7]. The reasonably low cost of CNF preparation compared to other synthetic and bioinspired nanomaterials raises an excellent opportunity to use them as reinforcing elements in nanocomposites with wide-scale structural applications [8]. In addition, CNFs have a broad range of potential application in different sectors such as bio-based substitution for traditional plastics, reinforcement of composite materials, boosting paper properties, and a barrier material in packaging [5]. The commercialization of CNFs is still suffering from some barriers such as the high cost of raw materials and a high level of energy consumption for the production of CNFs, which needs to be addressed to enable their subsequent applications at the industrial level. Several attempts have recently been reported to reduce the finished-cost of CNFs by using cheaper pristine cellulose fibers and whole lignocellulosic fiber utilization [9-11]. Furthermore, an electrostatically induced swelling by subjecting cellulose fibers to oxidative pre-treatments or grafting procedures, or simply producing pulp with a high number of charged groups have also been proposed as cost-effective 
approaches for the preparation of CNFs [12,13]. Along this line, Zimmermann et al. [14] found that wheat straw, recycled paper, and choice of proper pretreatment may reduce the final price of CNF production. The mechanical energy consumption of CNFs with different qualities has been extensively investigated and it was concluded that the selection of optimized pretreatment along with mechanical processing could be a necessity for a cost-effective approach of CNFs compared to petroleum-based plastics in packaging [15]. Extensive chemical pretreatment has also been performed as a route to reduce the energy input required to isolate the nanofibers [16]. Naderi et al. [17,18] used carboxymethyl cellulose as an additive for wood pulp in order to facilitate the microfluidization process and obtain energy-efficient CNFs. Despite the reported attempts, the high energy requirement for $\mathrm{CNF}$ production still excludes their entry into the broader commercial market. It is worthy to note that all processes applied for the production of CNFs were not competitive and therefore, the finished cost of CNFs is relatively high. To the best of our knowledge, there is no updated, consolidated, and comprehensive information about the recent development on optimizing the energy consumption of CNF production and introducing energy-efficient processes in the literature. Thus, this review addresses the modifications and innovation in CNF preparation strategies from several standpoints of view such as using cheaper raw materials, applying different effective pretreatments, and efficient-mechanical processes to produce CNFs through energy-efficient approaches.

\section{Pristine Fibers}

In order to make CNFs commercially viable, their supply chain from fiber resource to extraction processes needs to be optimized. Besides the production cost, considerable attention is required as the morphological properties of CNFs depend on the source of the cellulose, preparation methods, and processing conditions [19]. All lignocellulosic fiber sources vary in chemical constituents as well as the morphology of the plant cell wall (i.e., length, diameter, and cell wall types). In particular, the amount of cellulose, hemicellulose, lignin, and extractives differs not only between the lignocellulosic fibers, but also between various species at different growing geographies. Additionally, cellulose sources differ significantly in their values of crystallinity, fiber length, fiber diameter, and microfibril angle (MFA) [20]. Although woody cellulose fibers are the most popular resource for the production of CNFs, non-woody cellulose fibers are currently being investigated as potential pristine cellulose fibers for the production of varying qualities of CNFs [11]. Facile processing, low energy consumption, vast abundance, low-cost, low lignin content, and renewability are considered as some of the promising features of nonwoody CNFs. Annual agricultural crops such as flax, hemp, kenaf, sisal, cotton, and agricultural residues including sugar cane bagasse, wheat, and rice straw are some non-woody cellulose fibers that have been employed to produce CNFs in the literature [2,21-23]. It is noteworthy that woody cellulose fibrils are mainly found in the secondary cell wall, while cellulose fibrils from agricultural fibers are in the primary cell wall, and thus easier to liberate with less energy demand and less time consumption. In addition, shorter fiber length and thinner cell wall of the non-wood residue compared to wood plant result in processing with no homogenizer clogging, no limitation in inlet consistencies, and low energy demand due to higher feeding consistencies of pristine fibers. Therefore, these low-cost materials are considered as an emerging alternative for the production of CNFs with acceptable properties in an increasingly environmentally friendly circular bio-economy.

\subsection{Non-Wood Plant Cellulose Fibers}

Zimmermann et al. [14] were the first researchers who used non-wood lignocellulosic fibers such as wheat straw for producing CNFs. They concluded that wheat straw with smaller dimensions (reduced in lengths and diameters) needed a shorter processing time compared to wood-based cellulosic fibers through the inline dispersing, and fewer passes through the high-shear homogenizer. In fact, they showed that wheat straw pulp required $30 \mathrm{~min}$ for processing via inline dispersing, while beech wood pulp required $60 \mathrm{~min}$ for 
processing. Later on, Ferrer et al. [24] described the CNF preparation from empty palm fruit bunch fibers (EPFBF) using different sulfur-free pulping systems such as $\mathrm{NaOH}-\mathrm{AQ}$, formic and hydrochloric acid (Formosolv), formic acid, and hydroxide peroxide (Milox). The resulting CNFs possessed unique properties favorably comparable with wood CNFs, thus represents a value-added raw material for nanopaper production. In another effort, Hassan et al. [25] investigated the capability of date palm fruit stalks (DPFS) as an underutilized agricultural residue for the production of microfibrillated cellulose (MFC) through enzyme assisted pretreatment. Josset et al. [26] measured the energy consumption of CNF production from wheat straw cellulosic fibers. Their results demonstrated that energy consumption increased almost linearly after two grinding cycles. The whole treatment of wheat straw cellulosic fibers consumed $5.75 \mathrm{kWh} / \mathrm{kg}$ on a dry-weight base, while bleached softwood-based pulp fibers required $5.25 \mathrm{kWh} / \mathrm{kg}$ to liberate. Suopajärvi et al. [27] conducted a competitive study on two different kinds of cellulose fiber sources including wheat straw and birch for the production of CNFs. The produced wheat straw cellulose fibrils were shorter than the birch cellulose, fibrils, and the downsizing of fiber to nanofibrils was easier during the homogenization. In addition to processing costs, the final properties of CNFs strongly depend on the processing techniques, which have been extensively evaluated in the literature. Table 1 summarizes the different mechanical approaches for the production of CNFs from different non-wood plant fibers and their corresponding characteristics.

Table 1. Different mechanical routes for the production of CNFs prepared from various non-wood plant fibers and their relevant characteristics.

\begin{tabular}{|c|c|c|c|c|}
\hline Pristine Raw Material & Mechanical Process & $\begin{array}{c}\text { Energy Consumption } \\
(\mathrm{kWh} / \mathrm{kg})\end{array}$ & $\begin{array}{l}\text { CNFs Diameters } \\
(\mathrm{nm})\end{array}$ & Reference \\
\hline Sugar beet & Homogenization & N.D * & - & [28] \\
\hline $\begin{array}{l}\text { Wheat straw } \\
\text { Soy hull }\end{array}$ & $\begin{array}{l}\text { Homogenized at } \\
\text { pressure } \geq 300 \mathrm{bar}\end{array}$ & N.D & $\begin{array}{c}10-80 \\
20-120\end{array}$ & [29] \\
\hline Banana rachis & Waring blender & N.D & $3-5$ & [30] \\
\hline $\begin{array}{c}\text { Wheat straw } \\
\text { Refined fibrous wheat } \\
\text { straw }\end{array}$ & $\begin{array}{c}\text { HPH } \\
\text { Microfluidization }\end{array}$ & $\begin{array}{l}\text { Requires fewer passes } \\
\text { through } \mathrm{HPH}\end{array}$ & $\begin{array}{l}\text { Homogenous } \\
\text { network structures } \\
\text { (less than 100) }\end{array}$ & [14] \\
\hline $\begin{array}{l}\text { Unbleached kenaf bast } \\
\text { fiber } \\
\text { Bleached kenaf bast fiber }\end{array}$ & $\mathrm{HPH}$ & N.D & $\begin{array}{l}20-40 \\
10-30\end{array}$ & {$[31]$} \\
\hline Kenaf core fibers & $\mathrm{HPH}$ & N.D & $20-25$ & [32] \\
\hline $\begin{array}{l}\text { Empty fruit bunches (EFB) } \\
\text { of oil palm }\end{array}$ & $\mathrm{HPH}$ & N.D & $5-40$ & [33] \\
\hline Sugarcane bagasse & $\begin{array}{l}\text { Ultrafine grinder } \\
\text { Microfluidization }\end{array}$ & N.D & $5-15$ & [34] \\
\hline Rice straw & $\begin{array}{l}\text { Ultrafine grinder } \\
\text { Microfluidization }\end{array}$ & N.D & $4-13$ & {$[34]$} \\
\hline $\begin{array}{l}\text { Empty Palm Fruit Bunch } \\
\text { Fibers (EPFBF) }\end{array}$ & $\begin{array}{c}\mathrm{HPH} \\
\text { Microfluidization }\end{array}$ & N.D & $10-30$ & [24] \\
\hline Unbleached kenaf pulp & Microfluidization & N.D & Less than 100 & [35] \\
\hline Wheat straw & $\begin{array}{c}10 \text { times grinding at } 1500 \\
\text { rpm }\end{array}$ & 5.75 & N.D & [26] \\
\hline Corn husk & $\begin{array}{l}\text { High intensity } \\
\text { ultrasonication }\end{array}$ & N.D & 50 to 250 & [36] \\
\hline $\begin{array}{c}\text { Triticale crop residue } \\
\text { Fiber oxidized with } \\
\text { TEMPO }\end{array}$ & $\begin{array}{c}\text { HPH } \\
\text { High speed blender }\end{array}$ & $\begin{array}{l}40-45 \\
9-12\end{array}$ & $20-30$ & [37] \\
\hline Bleached bagasse kraft & Microgrinding & 33.55 & $23.58 \pm 8.63$ & [38] \\
\hline Unbleached soda rice straw & Microgrinding & 11.4 & $\leq 17$ & [22] \\
\hline $\begin{array}{c}\text { Unbleached NSSC rice } \\
\text { straw }\end{array}$ & Microgrinding & 11.2 & $\leq 17$ & [22] \\
\hline
\end{tabular}


More recently, sugarcane bagasse was used as a cheap pristine fiber in CNFs production through micro-grinding with enzymatic pretreatment [38] and no pretreatment [38]. Bleached bagasse fibers consumed a specific total energy of $33.55 \mathrm{kWh} / \mathrm{kg}$ for $2 \mathrm{~h}$ of grinding to downsize the CNFs, whereas enzymatic pretreatment reduced the specific total energy consumption by $11.83 \%$. In this connection, unbleached bagasse fiber was also used for the production of lignin-rich CNFs through $2 \mathrm{~h}$ grinding with an energy consumption of $\simeq 9-10 \mathrm{kWh} / \mathrm{kg}$. Extending the micro-grinding time to $2 \mathrm{~h}$ increased the energy consumption considerably ( $\simeq$ twofold). In another research work, in general, agricultural by-products are receiving more attention in introducing a commercially competitive route for CNF production since non-wood plant fibers contain less lignin than wood, and their pulping and bleaching processes require lower energy. Other examples of non-wood fibers with potential application in CNFs extraction include those obtained from the cultivation of corn, sorghum, sugarcane, rice straw, barley, pineapple, bananas, coconut crops, and corn husk $[3,21]$.

\subsection{Pulp and Paper Mill Sludge}

According to the national council for air and stream improvement, the paper industry was the primary producer of water treatment-plant residuals or well-known sludge in the world. It has produced 5.83 million tons of the residuals, in which only $23 \%$ was practically employed, while $51 \%$ was landfilled or lagoon stored, and another $26 \%$ was burned [39-42]. The possible applications of sludge as a cheap raw material in pulp and paper, and the cellulose derivatives industry has been reported. As mentioned earlier, this cheap, accessible, abundant, and sustainable raw material can practically be considered as an emerging raw material for the production of CNFs [33,43,44]. Similarly, Joonobi et al. [33] suggested that sludge of cellulose (dissolving pulp) could be used as an alternative and potential source for scaled-up production of CNFs. They reported that the energy consumption for isolating nanofibers through ultrafine grinding from cellulose and sludge was 1.7 and $1.3 \mathrm{kWh} / \mathrm{kg}$, respectively. Overall, they reported that the grinder with low rotor-speed (1440 rpm) was found to be more energy-efficient compared to the high speed for mechanical fibrillation. In another attempt, Adu et al. [44] conducted comparative research on two different types of pristine fibers including never dried and dried paper mill sludge for CNF production. They found that these starting materials required no specific pretreatment for the production of CNFs. The energy consumption for the fibrillation of cellulose from PSNFND and PSNFD paper mill sludge was found to be $8.5 \mathrm{kWh} / \mathrm{kg}$ and $9.3 \mathrm{kwh} / \mathrm{kg}$, respectively. The higher energy consumption in PSNFD was more likely contributed to a well-known phenomenon (i.e., hornification), which usually happens during drying of cellulose and facilitates an irreversible bonding between cellulose fibrils and enhanced degree of crosslinking between cellulose microfibrils due to additionally formed hydrogen bonding $[45,46]$. It is worth mentioning that pivotal issues such as the variability in sludge chemical composition from different pulp mills should be considered in order to scale-up the production of CNFs [44].

\subsection{Secondary Cellulose Fibers}

The main (10-39\%) ingredients of mixed municipal solid waste are paper and board [47]. Ultimately, the better use of secondary fibers will result in higher resource efficiency, avoiding resource depletion and unnecessary disposal of useful wastes. Nowadays, these undervalued cellulose sources provide a potential of pristine cellulose fibers for the production of CNCs [48] and CNFs [49,50]. Paper produced from repeated recycled fibers is far weaker than a paper made from virgin pulps and can be considered for the production of cellulose nanomaterials. Wang et al. [49] reported that CNFs prepared from an old corrugated container (OCC) via ultrafine grinding followed by ultrasonication had an ultra-long cellulose fibril structure with an average diameter ranging from $30 \mathrm{~nm}$ to $100 \mathrm{~nm}$. Josset et al. [26] evaluated the energy consumption and CNF quality of recycled newsprint $(\mathrm{RN})$ and virgin cellulose fibers including wheat straw and bleached wood 
cellulose fibers. They deduced that there was a linear relationship between energy consumption and grinding cycles with an energy-consumption rate of ca. $0.7 \mathrm{kWh} / \mathrm{kg}$ per grinding cycle (i.e., after 10 cycles of grinding, wood fibers consumed $5.25 \mathrm{kWh} / \mathrm{kg}$, while, wheat straw and recycled newsprint fibers consumed $5.75 \mathrm{kWh} / \mathrm{kg}$ and $6.75 \mathrm{kWh} / \mathrm{kg}$, respectively). A different approach was reported by Wang and Zhou [50], who examined mixed office paper (MOP) without deinking for the production of CNFs. They reported that energy consumption for MOP during grinding was $17 \%$ lower than fibrillation of bleached kraft eucalyptus cellulose fiber after $3 \mathrm{~h}$. This was more likely attributed to the presence of $18 \%$ filler that effectively reduced the number of fibers. This, in turn, reduced the required energy for fiber breakup during the grinding step. Another research group reported the energy consumption of CNF production from different municipal solid waste paper (MSWP) through ultrafine grinding between 6.6 and $13.1 \mathrm{kWh} / \mathrm{kg}$, depending on the purification pretreatment methods applied (i.e., pulping, flotation, and washing) and the number of impurities in the pristine materials [47]. MSWP fiber after pulping and floatation pretreatments represented the lowest grinding time of about $134 \mathrm{~min}$ and consumed the minimum grinding energy $(6.6 \mathrm{kWh} / \mathrm{kg})$.

\subsection{The Effect of Noncellulosic Components on Fibrillation}

\subsubsection{The Vital Role of Hemicellulose}

Generally, the higher the hemicellulose content in the cellulose fibers, the higher the yield of the nanofibrillated material and the lower energy consumption during the mechanical treatment [9,51-54]. Hemicelluloses can surround the cellulose fibrils thanks to their hydrated amorphous character, carboxyl groups, and branched structures. Basically, hemicelluloses behave as a protective colloid, hampering cellulose fibrils and impeding the formation of irreversible hydrogen bonds between cellulose fibrils. The lowest energy consumption $(8.2 \mathrm{kWh} / \mathrm{kg})$ was reported for rapeseed stalk cellulose fibers when the mechanical fibrillation process using a waring blender was conducted followed by the $\mathrm{D} 2-\mathrm{O} 2\left(\mathrm{NaClO}_{2}\right.$ delignification and TEMPO-NaBr-NaClO oxidation) [54]. However, corn stalk and rice straw cellulose fibers consumed 12 and $14.8 \mathrm{kWh} / \mathrm{kg}$, respectively, under the same condition (CNF yield 60\%). Furthermore, the application of a high-pressure homogenizer led to an approximately four-fold growth in energy consumption for the same D2-O2 treated cellulose fibers. In particular, rapeseed stalk, corn stalk, and rice straw cellulose fibers consumed 35,40 , and $52 \mathrm{kWh} / \mathrm{kg}$, respectively. The amount of mechanical energy required for the downsizing of hemicellulose-rich pristine cellulose fibers has still not been quantitatively reported.

\subsubsection{The Importance of Residual Lignin on the Energy-Efficient Process}

The preparation of CNFs from various pristine fibers such as wood, non-wood plant fibers, secondary fibers, pulp, and paper mill sludge depends entirely on fully bleached cellulose fibers. However, unbleached pulps offer a significant improvement in the CNF quality and process effectiveness including total energy-saving and diminishing pollutants loads from bleaching treatments. In this review and hereafter, CNFs produced from unbleached, semi-bleached, and residual lignin-containing cellulosic fibers or pulps are referred to as "lignocellulosic nanofibers (LCNFs)". Heretofore, different types of lignin-containing starting cellulose fibers have been used for the preparation of LCNFs $[10,22-24,55-65]$. LCNFs are of interest due to their high compatibility with different polymers, huge application in the bio-based packaging sector, and environmentally friendly production, which prevents hazardous substances being released. A focal point of the current section is to explore how the delignification process and residual lignin affect energy consumption during the mechanical fibrillation process. In agreement with a recently published work [66], Ferrer et al. [24] reported that residual lignin content (about $\leq 1-3 \%$ ) improved LCNF yield with a smaller pore structure, fibril diameter, higher surface area, and an increased interaction with water due to its charge density, mechano-radical effects (radical scavenging ability), and amorphous structure. The nanopapers prepared 
from LCNFs in this study also exhibited better mechanical properties than those with no residual lignin. Jiang et al. [66] reported that the LCNFs containing more residual lignin consumed slightly lower energy during the defibrillation process through the microgrinding approach. In general, the residual lignin delayed the fibrillation at the initial stage, and if the fibrillation process prolonged further, the cellulose fibers containing more residual lignin displayed the highest fibril yields. Recently, there is also increased attention to applying lignin-containing starting materials for the production of LCNFs [67-70]. The energy consumption for bagasse cellulose fibers with different residual lignin of $14.9 \%$, $2.4 \%$, and $0.1 \%$ was measured to be $36 \mathrm{kWh} / \mathrm{kg}, 37 \mathrm{kWh} / \mathrm{kg}$, and $39 \mathrm{kWh} / \mathrm{kg}$ for $7 \mathrm{~h}$ of grinding, respectively. The energy consumption of various pristine cellulose fibers after different passes through the grinder was reported as bleached softwood (Radiata Pine) kraft pulp, $13.3 \mathrm{kWh} / \mathrm{kg}$; bleached hardwood kraft pulp (Acacia), $19.34 \mathrm{kWh} / \mathrm{kg}$; hardwood CTMP (poplar), $15.3 \mathrm{kWh} / \mathrm{kg}$; and unbleached softwood (Pinus sylvestris) kraft pulp, $13.3 \mathrm{kWh} / \mathrm{kg}$. The higher energy consumption of bleached hardwood cellulose fibers $(19.34 \mathrm{kWh} / \mathrm{kg})$ compared to the softwood $(13.3 \mathrm{kWh} / \mathrm{kg})$ was due to the more rigid, complex, and heterogeneous structure of hardwood fibers. He et al. [71] suggested that the low energy consumption of the CTMP cellulose fibers was also due to the highest fines content initially presented, which meant that the exposed cross-sections in fines were more accessible to fibrillation (Figure 2).

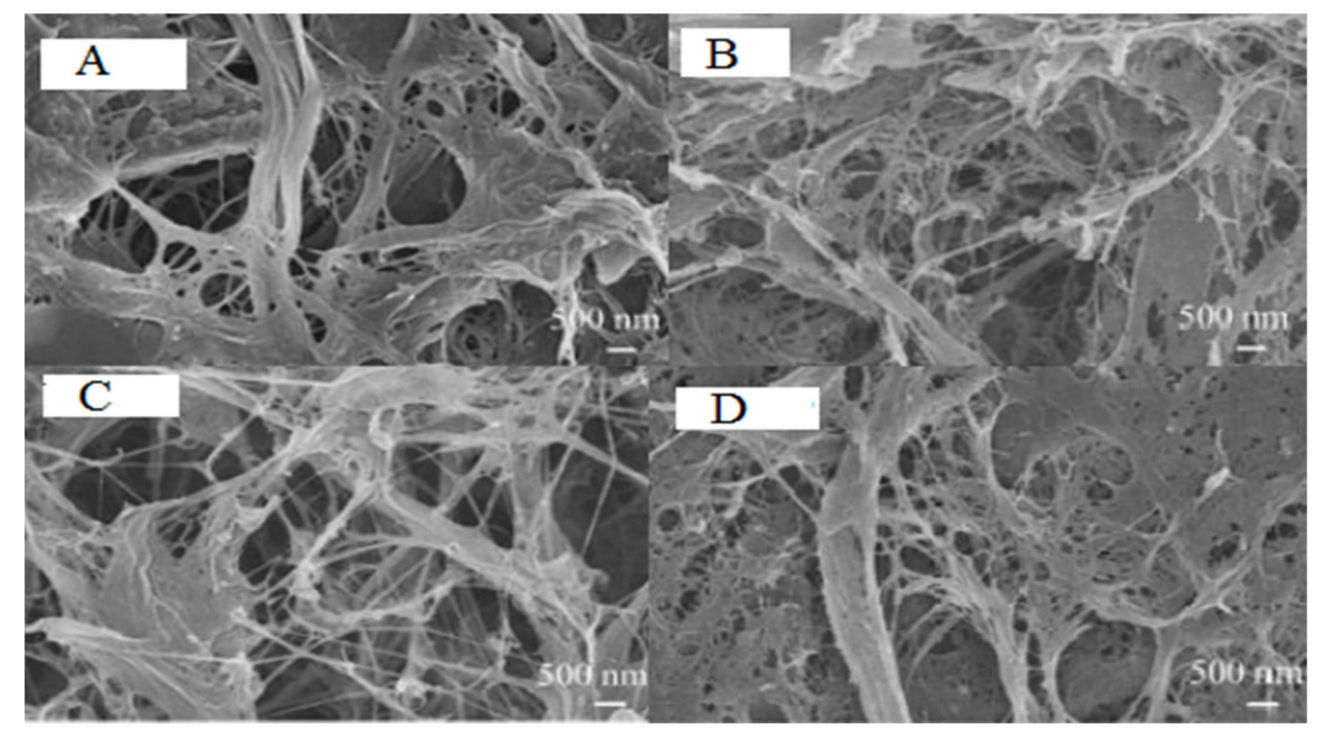

Figure 2. Field emission electron scanning microscopy (FESEM) images of CNFs, prepared from poplar CTMP (A), unbleached Pine kraft pulp (B), bleached Pine kraft pulp (C), and bleached Acacia kraft pulp (D) [71]. All permissions obtained through Rights Link ${ }^{\circledR}$.

Overall, three primary mechanisms have been suggested for the importance of the residual lignin on the fibrillation process of LCNFs: (1) the residual lignin could boost the fibril yield via hindering the prepared LCNFs from recombination [66]; (2) the nonetherified phenolic groups of residual lignin (i.e., ortho-methoxy groups, hydroxyl groups, and the double bond between the outermost carbon atoms in the side chain are able of scavenging radicals $[10,24,65,67])$; and (3) very active radicals of cellulose fibrils due to high density of hydroxyl groups and improved specific surface area could react with lignin nanoparticles and form very stable structures $[10,66]$. Therefore, the residual lignin in the LCNF structures could remarkably diminish the interfibrillar hydrogen bonding and inhibit the LCNFs from the formation of flocks or bundles $[65,66,68,69]$. The lignin nanoparticles are clearly distinct in Figure 3A,B (i.e., large amounts of spherical-like lignin nanoparticles (red circles)). 
A

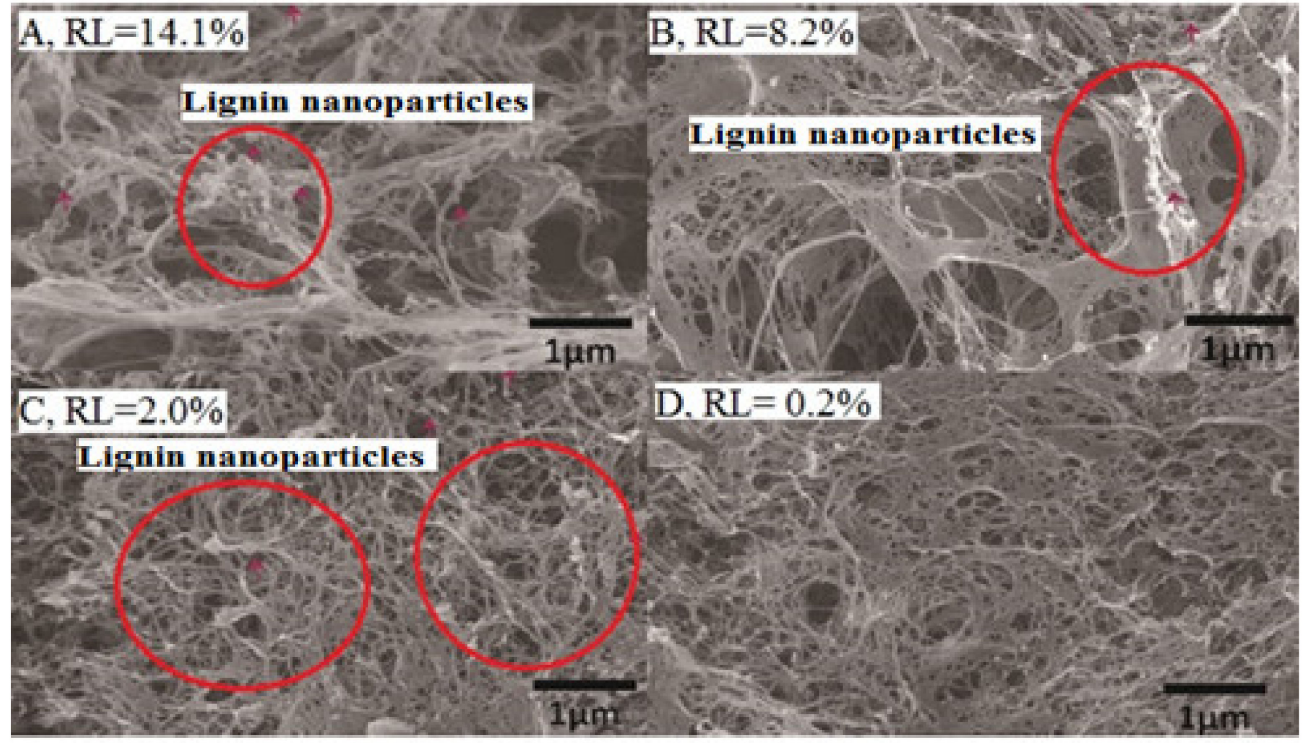

B

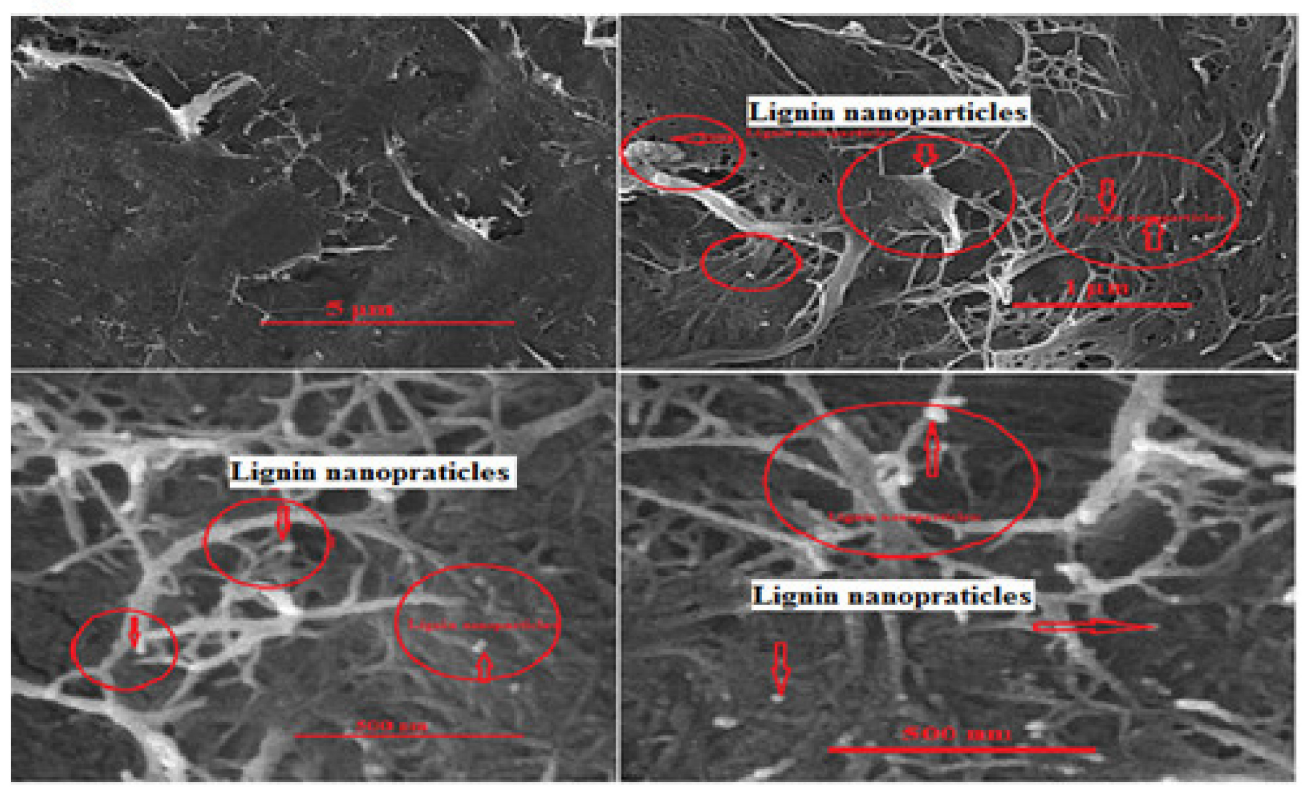

Figure 3. Field emission electron scanning microscopy (FESEM) images of LCNFs (A), prepared from poplar with high lignin content $(\mathrm{A}, \mathrm{RL}=14.01 \%)$, medium lignin content $(\mathrm{B}, \mathrm{RL}=8.2 \%)$, low lignin content $(C, R L=2 \%)$, and very low lignin content $(D, R L=0.2 \%)$ [71]. Permission obtained through Rights Link ${ }^{\circledR}$ and (B) of LCNFs, prepared from chemi-mechanical (CMP) hardwood pulps (unpublished data). The red arrows and red circles indicate lignin nanoparticles (LNPs).

As can be observed in Table 2, the total energy consumption during the mechanical liberation of lignin-containing starting materials was lower than bleached cellulose fibers. A decisive property of LCNFs compared to CNFs is attributed to a high-water contact angle, which is promising for the potential applications in the sustainable and bio-based packaging industries. Here, it was pointed out that not only is the production of LCNFs from agricultural residues via an energy-efficient process economically possible, but also that its LCNF properties such as tensile strength and modulus of elasticity could surpass those of the wood-based ones. 
Table 2. Important characteristics of LCNFs prepared from different pristine cellulose fibers.

\begin{tabular}{|c|c|c|c|c|c|c|c|}
\hline Pristine Fibers & $\begin{array}{l}\text { Residual } \\
\text { Lignin } \\
(\%)\end{array}$ & $\begin{array}{c}\text { Type of } \\
\text { Mechanical } \\
\text { Approach }\end{array}$ & $\begin{array}{c}\text { LCNF Yield } \\
(\%)\end{array}$ & $\begin{array}{l}\text { LCNF } \\
\text { Diameter } \\
(\mathbf{n m})\end{array}$ & $\begin{array}{l}\text { Energy } \\
\text { Consump- } \\
\text { tion } \\
(\mathbf{k W h} / \mathbf{k g})\end{array}$ & $\begin{array}{l}\text { Water } \\
\text { Contact } \\
\text { Angle } \\
\left({ }^{\circ}\right)\end{array}$ & Reference \\
\hline $\begin{array}{l}\text { Birch kraft pulp: } \\
\text { Unbleached } \\
\text { Oxygen delignified }\end{array}$ & $\begin{array}{l}2.2 \\
1.5\end{array}$ & Grinder & - & - & & - & [20] \\
\hline $\begin{array}{c}\text { Birch: } \\
\text { Unbleached } \\
\text { Oxygen delignified }\end{array}$ & $\begin{array}{l}2.7 \\
1.9\end{array}$ & $\mathrm{HPF}$ & - & $\begin{array}{l}10-40 \\
10-40\end{array}$ & - & $\begin{array}{l}60 \pm 6 \\
54 \pm 6\end{array}$ & [9] \\
\hline $\begin{array}{c}\text { Softwood kraft pulp: } \\
\text { Bleached } \\
\text { Unbleached } \\
\text { CTMP } \\
\text { TMP }\end{array}$ & $\begin{array}{c}1.0 \\
2.6 \\
20.6 \\
25.6\end{array}$ & Grinder & $\begin{array}{c}20 \\
15 \\
9 \\
2\end{array}$ & - & - & - & [21] \\
\hline $\begin{array}{l}\text { SEW fiber of spruce: } \\
\text { Low lignin } \\
\text { Medium lignin } \\
\text { High lignin }\end{array}$ & $\begin{array}{c}1.7 \\
3.7 \\
13.5\end{array}$ & $\mathrm{HPF}$ & - & $\begin{array}{l}44 \pm 3 \\
20 \pm 2 \\
16 \pm 2\end{array}$ & & $\begin{array}{l}49 \\
61 \\
78\end{array}$ & [22] \\
\hline $\begin{array}{l}\text { Wheat straw: } \\
\text { TO-LCNF } \\
\text { Mec.LCNF } \\
\text { Enz. LCNF }\end{array}$ & 17.7 & $\begin{array}{l}- \\
\mathrm{HPH} \\
\mathrm{HPH} \\
\mathrm{HPH}\end{array}$ & $\begin{array}{l}\geq 95 \\
55.6 \\
37.45\end{array}$ & $\begin{array}{c}6.81 \\
14.01 \\
14.52\end{array}$ & - & - & [23] \\
\hline $\begin{array}{c}\text { Pine kraft } \\
\text { Poplar CTMP }\end{array}$ & $\begin{array}{c}6.82 \\
18.81\end{array}$ & Grinder & - & - & $\begin{array}{l}15.49 \\
15.25\end{array}$ & - & [18] \\
\hline $\begin{array}{c}\text { Rice straw pulp: } \\
\text { Soda } \\
\text { Soda-Enz. } \\
\text { NSSC } \\
\text { NSSC-Enz }\end{array}$ & $\begin{array}{c}16.43 \\
8.06 \\
7.98 \\
14.15 \\
13.18\end{array}$ & Grinder & & $\begin{array}{l}13 \pm 5 \\
11 \pm 5 \\
17 \pm 6 \\
14 \pm 7\end{array}$ & $\begin{array}{l}11.4 \\
10.5 \\
11.2 \\
13.5\end{array}$ & $\begin{array}{l}61.4 \\
60.3 \\
69.7 \\
63.9\end{array}$ & [15] \\
\hline $\begin{array}{c}\text { Poplar: } \\
\text { High lignin } \\
\text { Medium lignin } \\
\text { Low lignin } \\
\text { Very low Lignin }\end{array}$ & $\begin{array}{c}22.1 \\
14.1 \\
2.0 \\
0.2\end{array}$ & Grinder & - & $\begin{array}{l}15.1 \pm 3.5 \\
16.4 \pm 3.3 \\
15.4 \pm 3.4 \\
17.1 \pm 3.5\end{array}$ & - & $\begin{array}{c}45 \\
41.2 \\
16.5 \\
9.3\end{array}$ & [24] \\
\hline $\begin{array}{c}\text { Organosolv bagasse } \\
\text { pulp: } \\
\text { High lignin } \\
\text { Medium lignin } \\
\text { Low lignin }\end{array}$ & $\begin{array}{c}14.91 \\
2.41 \\
0.11\end{array}$ & Grinder & $\begin{array}{l}51 \\
46 \\
39\end{array}$ & $\begin{array}{l}9.2 \pm 3.3 \\
22.7 \pm 6.7 \\
32.9 \pm 7.7\end{array}$ & $\begin{array}{l}39 \\
38 \\
37\end{array}$ & - & [19] \\
\hline $\begin{array}{l}\text { Kraft bagasse pulp: } \\
\text { Medium lignin } \\
\text { Low lignin }\end{array}$ & $\begin{array}{l}2.7 \\
0.1\end{array}$ & Grinder & $\begin{array}{l}46 \\
39\end{array}$ & & $\begin{array}{l}38 \\
37\end{array}$ & - & [14] \\
\hline $\begin{array}{l}\text { Hardwood } \\
\text { Chemi-mechanical } \\
\text { (CMP) pulps: } \\
\text { High lignin } \\
\text { Medium lignin } \\
\text { Low lignin }\end{array}$ & $\begin{array}{l}18.8 \\
10.9 \\
1.98\end{array}$ & $\begin{array}{l}\text { Grinder } \\
\text { Grinder } \\
\text { Grinder }\end{array}$ & $\begin{array}{l}- \\
-\end{array}$ & $\begin{array}{l}19 \pm 3.5 \\
30 \pm 7.3 \\
40 \pm 7.9\end{array}$ & $\begin{array}{l}2.1 \\
4.5 \\
5.4\end{array}$ & $\begin{array}{l}- \\
-\end{array}$ & [25] \\
\hline $\begin{array}{l}\text { Hardwood neutral } \\
\text { sulfite semichemical } \\
\text { (NSSC) pulps: } \\
\text { High lignin } \\
\text { Low lignin }\end{array}$ & $\begin{array}{c}16.8 \\
1.5\end{array}$ & $\begin{array}{l}\text { Grinder } \\
\text { Grinder }\end{array}$ & - & $\begin{array}{l}22 \pm 3.8 \\
35 \pm 6.5\end{array}$ & $\begin{array}{l}4.2 \\
5.1\end{array}$ & - & [25] \\
\hline
\end{tabular}




\section{Mechanical Approaches}

Three frequently used mechanical approaches for the production of both CNFs and LCNFs are common refiners, ultrafine supergrinders, or microgrinders, high pressure homogenizers (HPHs), and high pressure microfluidizers (HPMs) (Figure 4). Optimum selection of the aforementioned mechanical techniques relies on decisive factors such as type, morphological, and chemical characteristics of all kinds of the starting materials (Section 1), the fibrillation severity, final product specifications, and the end-use and final applications of the prepared CNFs and LCNFs.

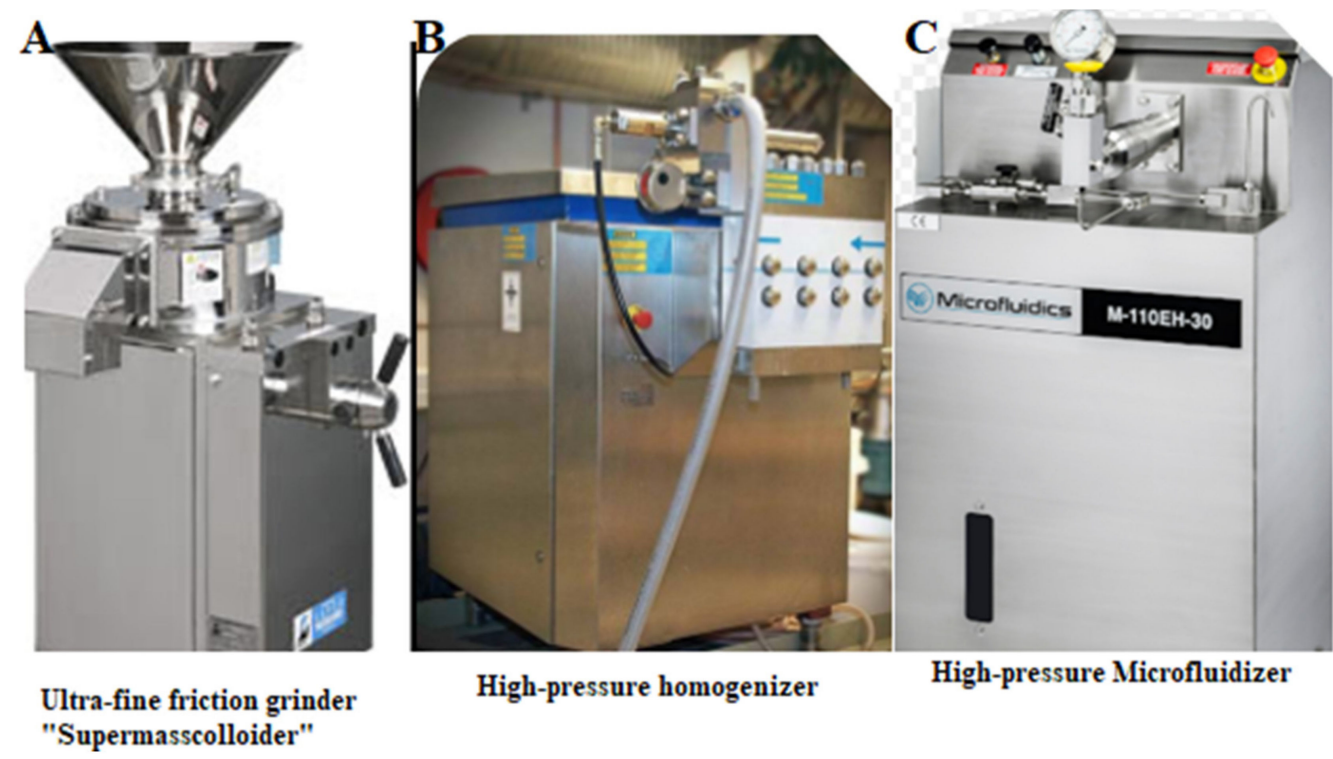

Figure 4. The three most common mechanical devices for the production of CNFs and LCNFs. (A) Ultrafine grinder, (B) high pressure homogenizer (HPH), and (C) high pressure microfluidizer (HPM).

\subsection{Microgrinding $(M G)$}

In a grinding process (Figure 4A), the dilute cellulose fiber suspension (usually 1$2.5 \%$ ) is forced through a gap into the ultrafine grinder where the upper stone is static, and the lower one is rotating. These stones are made of coarse silicon carbide (SiC) and have surfaces fitted with bars and grooves against which cellulose fibers are subjected to repeated cyclic stresses. Immediately after feeding, the rotor speed increases to 1440-1500 $\mathrm{rpm}$ to avoid the grinder blocking [21]. The centrifugal forces originating from the repeated cyclic pressure and shearing stress on the fiber suspension result in the fibrillation of the fibers being nanosized in diameter. Jonoobi et al. [33] investigated the efficacy of different rotor speeds (high speed of $3200 \mathrm{rpm}$ and low speed of $1440 \mathrm{rpm}$ ) as a critical processing parameter of the grinder on the energy consumption during the production of CNFs from paper sludge. The finding demonstrated a considerable difference in the specific energy consumption between the two rotor speeds where the grinder rotor with the low speed required less energy $(1.3 \mathrm{kWh} / \mathrm{kg})$ to downsize the paper sludge compared with that of the high speed $(3.1 \mathrm{kWh} / \mathrm{kg})$. This is more likely due to the fact that the cellulose fibers at the lower rotor-speed possess adequate time to act as a lubricating agent between the rotating and static discs, while the higher rotor-speed leads to more contact between the discs, resulting in an increase in temperature and thereby higher energy consumption [33].

\subsection{High Pressure Homogenizer (HPH)}

Nowadays, the production of CNFs usually consists of a mechanical refining and homogenizing process. For the refining step, both a disk refiner and valley beater are used. The HPH is widely used for the production of CNFs and LCNFs with different qualities at the lab, pilot, and industrial scales (Figure $4 \mathrm{~B}$ ). This technique involves forcing the diluted cellulose fiber suspension (0.5-1\%) through a very narrow channel or orifice 
using a piston, under a high pressure of 50-2000 bar. The width of the homogenization gap ranging from 5 to $20 \mu \mathrm{m}$ depends on the viscosity of the suspension and the applied pressure [72]. The created cavitation and shockwaves forces of HPH are powerful enough to downsize the cellulose fibers to CNFs and LCNFs. Nano-sizing the cellulose fibers can be obtained via a sudden pressure drop, high shear force, turbulent flow, and interfiber collisions against each other [73]. The extent of the cellulose liberation relies on the number of passages through the homogenizer and the applied pressure $[9,74]$. Production of CNFs and LCNFs through HPH now faces various problems including insufficient disintegration of the cellulose fibers, clogging of the homogenizer, high energy consumption, crystalline structure disruption, and the repeated mechanical treatment necessity for achieving high-quality CNFs. To prevail against the aforementioned obstacles, different solutions such as mechanical, enzymatic, and chemical pretreatments have been proposed (refer to Section 3).

\subsection{High-Pressure Microfluidizer (HPM)}

Nowadays, the high-pressure microfluidizer approach is incessantly being applied to various technologies for miniaturization from macrostructure to nano-dimensions $[75,76]$. HPM is categorized into (a) two-step single-channel microfluidization and (b) one-step dual-channel microfluidization [77]. Among the various mechanical approaches available, HPM has been shown to be one of the most energy-efficient processes for the preparation of CNFs and LCNFs [18,74], all cellulose composites (ACC) [78], and LCNFs [79] with uniform particle size. Generally, during microfluidization, dilute cellulose fiber suspension is forced through a defined fixed geometry with a narrow channel (either Y-type or Z-type) under high pressure (1500-2100 bar) (Figure 4C). Unlike HPH, which operates at a constant processing volume, the HPM operates at constant shear rate, which reduces the likelihood of clogs [75]. Furthermore, the fixed geometry of the interaction chambers ( $\mathrm{Y}$ and $\mathrm{Z}$ type) ensures reproducibility, especially when cellulosic and lignocellulosic fibers are processed multiple times $[14,74,80]$. The energy consumption of different mechanical approaches including microgrinding, $\mathrm{HPH}$, and HPM were evaluated by Spence et al. [15] for the first time. A significant difference observed for specific energy consumption per pass was reported as $1.1 \mathrm{kWh} / \mathrm{kg}$ and $0.17 \mathrm{kWh} / \mathrm{kg}$ for $\mathrm{HPH}$ and the micro-grinder, respectively. In particular, the HPM energy consumption was measured as $0.056,0.11$, and $0.175 \mathrm{kWh} / \mathrm{kg}$ per pass for the applied pressures of 690, 1380, and 2070 bar, respectively. As specified here, it was determined that for HPM, increasing the processing pressure and the number of passes from five to 20 times significantly increased energy consumption. It was concluded that five or eight passes or less were more efficient for HPM and HPH due to the effect of the number of passes on the minimal improvement in MFC film properties. The processing speed rates of cellulose fiber suspension for the production of MFC were measured to be nearly $2 \mathrm{~kg} / \mathrm{min}$ for micro-grinding, $1 \mathrm{~kg} / \mathrm{min}$ for microfluidiziation, and $0.2 \mathrm{~kg} / \mathrm{min}$ for homogenization. Naderi et al. [17] presented an innovative and a process-driven procedure for energy-efficient production of CNFs involving repeated homogenization of the cellulose fiber suspension at low applied homogenization pressures. The energy consumption during the HPM was calculated using the following equation (Equation (1)):

$$
\mathrm{EC} \mathrm{p,n}(\mathrm{kWh} / \mathrm{kg})=(2.2 \times 2 \times \mathrm{p} \times \mathrm{n}) /(1600 \times 1.2)
$$

where $2.2 \mathrm{kWh} / \mathrm{kg}$ is the energy consumed for a $2 \%(\mathrm{w} / \mathrm{w})$ carboxymethylated CNFs system at one time passing and 1600 bar; $p$ is the most used homogenization pressure; and $\mathrm{n}$ is the number of passes through the HPM.

The authors employed different pressures and several passes through the HPM. The energy consumption for four passes at 400 bar, four passes at 550 bar, and three passes at 850 bar were recorded and compared with most widely used pressures in the literature ( $\sim 1700$ bar). The results demonstrated a linear relationship between the number of passes through the HPM and the pressure, where enhancing the fraction of nano-sized entities 
increased the storage modulus and the energy consumption. The more passes through the HPM, the more fibrillated the materials, and the higher the energy consumption.

In addition to optimizing the energy consumption, the clogging problem of some mechanical instruments such as HPH and HPM during non-wood fiber processing should be taken into consideration. In order to overcome this drawback, it is necessary to reduce the size of fibers, especially softwood fibers, using several mechanical and chemical pretreatments before passing fibers through the instruments (Table 3). In this regard, bio-residue fibers such as agricultural residues (i.e., sugarcane bagasse [5,9] and wheat straw [81]) can be considered as efficient pristine materials due to a shorter fiber length, finer fiber diameter, and no need for a supplementary pretreatment.

Table 3. The processing conditions of the mechanical approaches for the preparation of CNFs.

\begin{tabular}{|c|c|c|c|c|}
\hline $\begin{array}{c}\text { Type of Mechanical } \\
\text { Process }\end{array}$ & $\begin{array}{l}\text { Initial Consistency } \\
\text { of Starting Material } \\
(\%)\end{array}$ & Fibrillation Systems & $\begin{array}{c}\text { Necessity of } \\
\text { Pre-Treatments }\end{array}$ & $\begin{array}{l}\text { Output } \\
(\mathrm{kg} / \mathrm{min})\end{array}$ \\
\hline Ultrafine grinding & $1-2.5$ & Disk grinding & No & 2 \\
\hline $\mathrm{HPH}$ & $0.5-1$ & Homogenization & $\begin{array}{l}\text { Compulsory; one of the } \\
\text { mechanical, enzymatic, } \\
\text { and chemical } \\
\text { pre-treatments }\end{array}$ & 1 \\
\hline $\mathrm{HPF}$ & 1 & Fluidization & $\begin{array}{l}\text { Compulsory; one of the } \\
\text { mechanical, enzymatic, } \\
\text { and chemical } \\
\text { pre-treatments }\end{array}$ & 0.2 \\
\hline
\end{tabular}

\subsection{Twin Screw Extruder (TSE)}

Today, there has been an increasing interest toward energy-efficient approaches for the preparation of CNFs. For the first time, a twin-screw extruder (TSE) was used as an emerging fibrillation method for the preparation of CNFs by Ho and co-workers [82]. The bleached kraft pulp was extruded at the concentration of $28 \mathrm{wt} \%$, and it was reported that this kind of pulp could successfully be disintegrated into high-quality fibrillated cellulose fibers (ca. $33-45 \mathrm{wt} \%$ solid content). TSE, as a top-down approach in producing $\mathrm{CNFs}$, showed better quality, higher inlet consistency, and lower energy consumption compared to HPH, HPF, and micro-grinding [82-86]. Baati et al. [83] reported that energy consumption during CNF fibrillation with TSE was estimated to be about $4.1 \mathrm{kWh} / \mathrm{kg}$, which a lower value than that required for HPH (between 30 and $50 \mathrm{kWh} / \mathrm{kg}$ ) or even for micro-grinding (between 5 and $30 \mathrm{kWh} / \mathrm{kg}$ ). The energy requirement for the production of CNFs in TSE was $63 \%$ lower than for producing CNFs from same starting material via the micro-grinding process [86]. Similar findings were reported for TSE and HPH, where the combination of one pass through TSE and two passes through HPH decreased the energy consumption by $45 \%$ [87]. The produced CNFs had a similar quality to CNFs produced after five passes through the homogenizer alone. Interestingly, passing the starting material once through the TSE increased the HPH feeding consistency from 2 to $4 \mathrm{wt} \%$. More recently, CNFs were successfully prepared from enzymatic and TEMPO-oxidized cellulose fibers using a twin-screw extruder equipped with kneading disks and fully flighted conveying screws (Figure 5) [84]. The produced CNFs were of high inlet consistency (20-25 wt $\%)$, and the method consumed $60 \%$ less energy compared to conventional processes. 


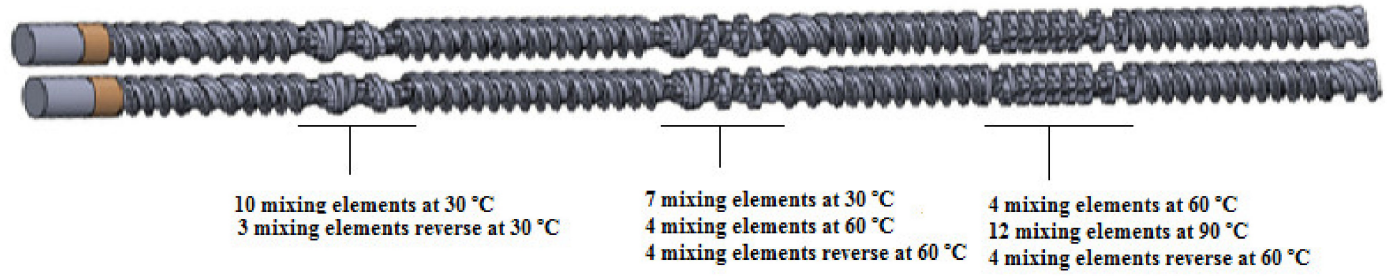

Figure 5. Different sections of a twin-screw profile for the preparation of CNFs [87].

Overall, TSE, as an emerging mechanical approach, is easy to implement without clogging during the disintegration process. It can be scaled up for high capacity and cost-effective production of CNFs at high consistency. However, optimization of the screw profile and other required TSE processing conditions to achieve the sufficient shear forces necessary for fibrillation of the fibers along with preventing the cellulose degradation remain challenges to overcome.

\section{Pretreatments}

\subsection{Enzymatic Pretreatment}

Many researchers have stated that well-documented enzymatic pretreatment decreased the energy consumption during the fibril liberation through HPH, HPM, [19,69,88-98], and micro-grinding [38,90]. Table 4 addresses different enzymes such as mono-component endoglucanase, and xylanase which have been employed to reduce the size and pre-defibrillate the fibers, thus reducing the frequency of equipment clogging. The use of enzymatic pretreatment not only reduces the processing cost by reducing the number of passes through the homogenizers, but also favors environmental efficiency in comparison with chemical methods. Pääkkö et al. [69] studied the application of mechanical shearing without enzymatic hydrolysis. Their results confirmed the preparation of non-homogeneous materials due to severe blocking during the homogenization step. Delgado-Aguilar demonstrated that enzymatic pretreatment prepared higher amounts of fibrils (69\%) compared to sole mechanical treatment (21\%). A set of enzymes used for the pretreatment of cellulose fibers were well-categorized by Henriksson et al. [88]:
A. Cellobiohydrolases: A and B type cellulases that attack the crystalline structure.
B. Endoglucanases: $\mathrm{C}$ and $\mathrm{D}$ type cellulases for breaking the amorphous region.
C. Lytic polysaccharide monooxygenase (LPMO).

Table 4. Different enzymes employed to pretreat the cellulose fibers on various raw materials before mechanical fibrillation for the production of CNFs.

\begin{tabular}{|c|c|c|c|c|}
\hline Starting Material & Used Enzyme & Process & Results & Reference \\
\hline $\begin{array}{l}\text { Bleached softwood } \\
\text { sulfite }\end{array}$ & Endoglucanase & $\mathrm{HPH}$ & $\begin{array}{l}\text { High aspect ratio, the stronger gel } \\
\text { network }\end{array}$ & [28] \\
\hline $\begin{array}{l}\text { Bleached softwood } \\
\text { sulfite }\end{array}$ & Endoglucanase & $\mathrm{HPH}$ & $\begin{array}{c}\text { High aspect ratio, lower DP, } \\
\text { Homogenous distribution of } \\
\text { nanofiber }\end{array}$ & [27] \\
\hline Bleached kraft bagasse & Cellulase, Xylanase & $\begin{array}{c}\text { Grinding and } \\
\text { homogenization }\end{array}$ & $\begin{array}{l}\text { Smaller diameter microfibrils } \\
\text { bands, reducing energy } \\
\text { consumption }\end{array}$ & [8] \\
\hline $\begin{array}{l}\text { Bleached softwood } \\
\text { pulp }\end{array}$ & Cellulase & Grinding & $\begin{array}{l}\text { Improving the efficiency of fibril } \\
\text { production, reduction in operating } \\
\text { cost }\end{array}$ & [29] \\
\hline $\begin{array}{l}\text { Bleached kraft } \\
\text { eucalyptus pulp }\end{array}$ & Cellulase & Microfluidizer & $\begin{array}{l}\text { Facilitating mechanical } \\
\text { homogenization, reducing the DP }\end{array}$ & {$[30]$} \\
\hline $\begin{array}{l}\text { Bleached soda date } \\
\text { palm fruit stalks }\end{array}$ & Xylanase & $\begin{array}{l}\text { High-shear ultrafine } \\
\text { friction grinder }\end{array}$ & $\begin{array}{l}\text { The larger diameter of nanofiber } \\
\text { and higher density and tensile } \\
\text { strength of CNF film }\end{array}$ & [31] \\
\hline Bleached soda bagasse & Endoglucanase & $\mathrm{HPH}$ & Better fibrillation & [32] \\
\hline
\end{tabular}


Table 4. Cont.

\begin{tabular}{|c|c|c|c|c|}
\hline Starting Material & Used Enzyme & Process & Results & Reference \\
\hline Banana peel & Xylanase & $\longrightarrow$ & $\begin{array}{l}\text { Higher aspect ratio, higher } \\
\text { crystallinity }\end{array}$ & [33] \\
\hline $\begin{array}{l}\text { Bleached kraft } \\
\text { hardwood }\end{array}$ & Novozym ${ }^{\circledR} 476$ & $\mathrm{HPH}$ & Higher fibrillation & [34] \\
\hline Soybean straw & $\begin{array}{c}\text { Enzymatic cocktail } \\
\text { (xylanse, } \\
\text { endoglucanse) }\end{array}$ & Turrax and sonication & The smaller diameter of nanofiber & [35] \\
\hline $\begin{array}{l}\text { Bleached kraft } \\
\text { eucalyptus pulp }\end{array}$ & $\begin{array}{c}\text { Purified and } \\
\text { commercial } \\
\text { Endoglucanase } \\
\text { (Ph-GH5) }\end{array}$ & Microfluidization & $\begin{array}{c}\text { Nanosize uniformity of CNFs, DP } \\
\text { reducing }\end{array}$ & [16] \\
\hline $\begin{array}{l}\text { Bleached softwood } \\
\text { pulp }\end{array}$ & $\begin{array}{l}\text { Mono-component } \\
\text { endoglucanase }\end{array}$ & Microgrinding & $\begin{array}{l}\text { Mechanical energy-saving, } \\
\text { uniformity of cellulose fibrils }\end{array}$ & [36] \\
\hline
\end{tabular}

Endo-cellulase randomly cleave internal hydrogen bonds at amorphous sites that create new chain ends. Additionally, Jeoh et al. [91] concluded that endo-cellulases hydrolyzed hydrogen bonds randomly at amorphous regions within a chain, which yielded shortened average chain lengths and broadened chain length dispersity at the surface with limited impact on total chain populations. Exo-cellulases cleave two to four units from the ends of the exposed chains produced by endo-cellulases, resulting in groups such as cellobiose [92] (Figure 6).

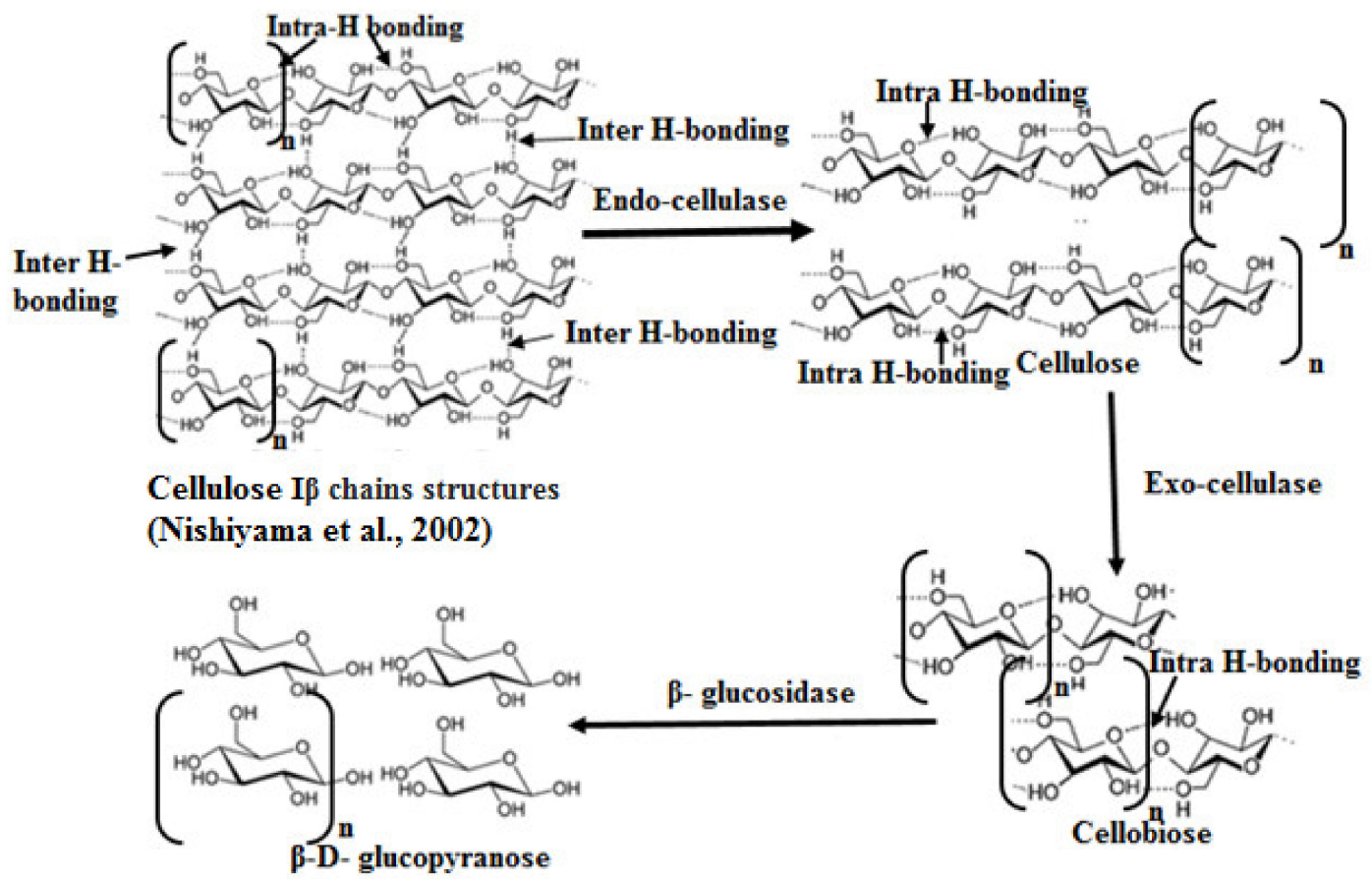

Figure 6. Proposed reactions of different cellulase enzymes on cellulose fibers [93].

Using a purified and well-characterized endoglucanase can eliminate unknown constituents in commercial endoglucanase, which may affect fibril length shortening. By using a selective enzyme (no reaction to xylan and xyloglucan, and low activity with soluble cello-oligosaccharides), it was shown that the purified enzyme pretreatment could reduce mechanical energy input. The energy consumption decreased at least $30 \%$ in comparison with prepared fibers with no enzymatic pretreatment. A recent study showed that the commercial endoglucanase enzyme was more aggressive in reducing DP and released fewer fine fibers compared to purified ones $[99,100]$. The CNFs through ultrafine grinding 
appeared to be less homogeneous in terms of fibril diameters, while in CNFs produced by high-pressure homogenization or microfluidization, large bundles of fibrils were observed [90]. On the effectiveness of post-treatment of the fibers on the production of CNFs, Wang et al. [90] reported that endoglucanase post-treatment efficiently improved the nanosize uniformity of CNFs from ultrafine grinding. More than $80 \%$ of the resultant $\mathrm{CNFs}$ had a diameter distribution between 5 and $9 \mathrm{~nm}$. The aforementioned treatment could be considered as an effective way for the production of nanosized uniform CNFs. Interestingly, commercial endoglucanase pretreatment at $0.01 \mathrm{mg} / \mathrm{g}$ cellulose fiber was much more effective than post-treatment under the same dosage for the production of $\mathrm{CNFs}$ with uniform fibril diameters. Commercial endoglucanase contains exoglucanase that may aggressively attack crystalline cellulose and lead to hydrolysis of disordered cellulose regions. However, purified ones may primarily work on non-crystalline regions of cellulose. In addition, xylanase enzyme generally attacks the amorphous regions, helps to cleave the covalent bond such as $\beta-1-4$ glycosidic linkage of xylan, and hydrolyzing part of the hemicellulose [90]. On the other hand, cellulases can access the amorphous region of cellulose by endoglucanase function or the extremity of the chain by the action of exoglucanases. Worth mentioning is the fact that no enzyme pre-treatment approach has led to extensive encumbrance and high energy consumption during $\mathrm{HPH}$, illustrating the necessity of enzymatic pretreatment through cellulose fiber homogenization. Enzyme dosage is an important aspect of pretreatment. Interestingly, CNFs produced from a combination of enzymatic pretreatment, and high shear homogenization exhibited long fibrils that led to the formation of an entangled network structure [5]. A $3 \mathrm{wt} \%$ enzymatic CNFs translucent gel with shear thinning behavior exhibited a storage modulus $\left(G^{\prime}\right)$ of $104 \mathrm{~Pa}$ [101]. The high viscosity of CNFs can be an interesting characteristic for some applications such as a rheology modifier in food or cosmetics [69]. It should be mentioned that the CNFs viscosity recovers over time when the shear forces are removed. Recently, the Technical Research Center (VTT) in Finland has developed HafCel ${ }^{\circledR}$ technology known as a low-cost method (energy cost $\sim 1 € /$ ton) for producing high consistency $\mathrm{CNFs}$ with low energy industrial mixers. This technology uses the commercially available cellulase enzyme, while the fibrillation degree can technically be adjusted by treatment time and applied enzyme concentration. The process yields very high consistency CNFs (tenfold increase in the solids content, i.e., $20-40 \%$ ), whereas conventional CNF production methods usually yield $1-3 \%$ consistency.

\subsection{Chemical Pretreatments}

\subsubsection{TEMPO-Mediated Oxidation}

In recent years, to decrease the mechanical energy required to downsize the cellulose structure through HPH and HPM, chemical pretreatment of cellulose fibers has become popular. This route converts the hydroxyl groups $(-\mathrm{OH})$ of cellulose fibers into carboxylate groups (COO-), thus creating anionic charges that subsequently turn into repulsive forces within the internal structure of the fibers (Figure 7). This also weakens the cellulose structure, which then facilitates the subsequent mechanical disintegration of the fibers to fibrils. In this direction, one of the preferred and well-documented pathways is the 2,2,6,6tetramethylpiperidine-1-oxyl (TEMPO) mediated oxidation with sodium hypochlorite and bromide and chlorite salts (TEMPO/NaClO $/ \mathrm{NaBr}$ or TEMPO/ $\mathrm{NaClO} 2 / \mathrm{NaClO}$ ) as the most common oxidizing agents $[2,12,16,52,102-110]$. The hydroxyl groups on the C6 of glucose units are converted to a carboxylic group. The nitroxyl radicals and nitrosonium salts as an oxidative route transform hydroxyl function into carboxyl and/or aldehyde groups [16,111-113]. 


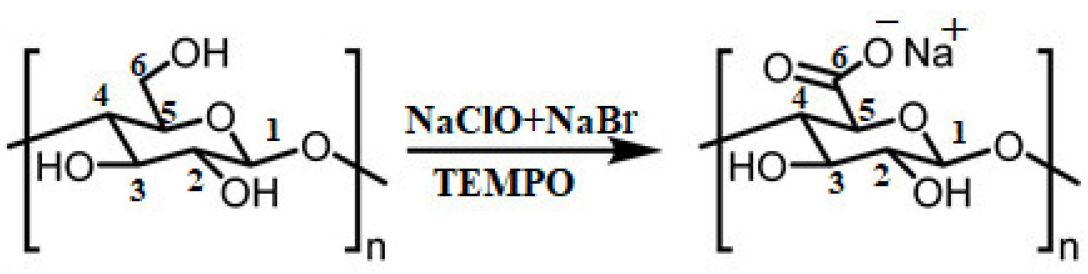

Figure 7. The most-applied approach of TEMPO-mediated oxidation of cellulose primary hydroxyl group to carboxyl groups.

Chemical modifications reduce the liberation energy of cellulose fibers from the order of $100 \mathrm{kWh} / \mathrm{kg}$ for unmodified cellulose preparations to as low as 1-2 kWh/kg [2,16,114,115], depending on the extent of the treatment $[16,115,116]$. The discovery of using TEMPOmediated oxidation as an energy-efficient pretreatment was introduced by Professor Akira Isogai, Associate Professor Tsuguyuki Saito, and Dr. Yoshiharu Nishiyama and they have honorably received the Wallenberg prize for this. This research group motivated more intensive research on CNFs and their applications in different fields. Through this method, the energy need reduced from 30,000 kWh/ton to $100-500 \mathrm{kWh} /$ ton, and the CNFs produced were more homogeneous than that of the enzymatic and no pretreated cellulose fibers. TEMPO-mediated oxidation was also applied to various kinds of native celluloses both wood [96,102,115,117,118] and non-wood cellulose fibers [116,119]. Okita et al. [12] reported that TEMPO-mediated oxidation (TEMPO/ $\mathrm{NaBr} / \mathrm{NaClO}$ system) procured more than $90 \%$ of the oxidized groups as a sodium carboxylate with zeta potentials of approximately $-75 \mathrm{mV}$ for different native celluloses. TEMPO-mediated oxidation converted almost all C6 primary hydroxyls on the surface of cellulose microfibrils to sodium carboxylate groups (approximately 1.7 groups $/ \mathrm{nm}^{2}$ ). Delgado-Aguilar et al. [96] evaluated the energy consumption of bleached kraft hardwood pulp (BKHW) through TEMPO-mediated oxidation and reported that TEMPO-oxidized fibers required fewer passes through $\mathrm{HPH}$ than other types of pretreatments. In this study, the mechanical energy required was approximately 4-7 kWh/kg [96]. Regarding energy consumption, Isogai et al. [115] reported that TOCN (TEMPO-Oxidized Cellulose Nanofiber) with $90 \%$ yield required $<1.94 \mathrm{kWh} / \mathrm{kg}$ for mild disintegration in an aqueous medium. The produced CNFs with a uniform width of 3-4 $\mathrm{nm}$, and length $<2-3 \mu \mathrm{m}$ proved to be promising materials for potential applications in packaging and display (e.g., high gas-barrier films), fine separation filters, health care materials, and nanofibers for composites. In general, in TEMPO treatment, the addition of more $\mathrm{NaClO}$ resulted in an increase in the density of carboxylate groups on the surface of the CNFs and the oxidation time [103]. With an increase in the amount of $\mathrm{NaClO}$ from 3.8 to $5.0 \mathrm{mmol} / \mathrm{g}$, the carboxylate content increased from only 0.2 to $0.3 \mathrm{mmol} / \mathrm{g}$, and the oxidation time increased from $40-45 \mathrm{~min}$ to $115-130 \mathrm{~min}$. Since, the most commonly used and ongoing chemical pretreatment is TEMPO-mediated oxidation, Table 5 presents the well-documented strategies that have been published thus far.

Table 5. Most-cited TEMPO-mediated oxidation pre-treatments addressed in the literature.

\begin{tabular}{|c|c|c|c|c|}
\hline Starting Materials & TEMPO System Used & Fibril Diameter (nm) & $\begin{array}{l}\text { Carboxylate Group } \\
\text { Content (mmol/g) }\end{array}$ & Reference \\
\hline $\begin{array}{l}\text { TEMPO-oxidized } \\
\text { spruce holocellulose } \\
\text { TEMPO-oxidized } \\
\text { Cotton linters } \\
\text { TEMPO-oxidized ramie }\end{array}$ & TEMPO, $\mathrm{NaBr}, \mathrm{NaClO}$ & $\begin{array}{c}\text { Crystal size }(\mathrm{nm}) 3.2 \\
6.2 \\
5.8\end{array}$ & $\begin{array}{l}1.16 \\
0.67 \\
0.94\end{array}$ & [37] \\
\hline $\begin{array}{l}\text { Never-dried hardwood } \\
\text { Once-dried hardwood }\end{array}$ & TEMPO, $\mathrm{NaBr}, \mathrm{NaClO}$ & $3-4$ & $\begin{array}{l}1.5 \\
1.5\end{array}$ & [38] \\
\hline $\begin{array}{l}\text { Softwood kraft pulp } \\
\text { Hardwood kraft pulp }\end{array}$ & TEMPO, $\mathrm{NaBr}, \mathrm{NaClO}$ & $3-4$ & $\begin{array}{l}1.5 \\
1.5\end{array}$ & [39] \\
\hline
\end{tabular}


Table 5. Cont.

\begin{tabular}{ccccc}
\hline Starting Materials & TEMPO System Used & Fibril Diameter (nm) & $\begin{array}{c}\text { Carboxylate Group } \\
\text { Content (mmol/g) }\end{array}$ & Reference \\
\hline Hardwood kraft pulp & $\begin{array}{c}\mathrm{TEMPO}, \mathrm{NaClO}_{2}, \\
\mathrm{NaClO}\end{array}$ & 5 & 0.8 & {$[40]$} \\
\hline
\end{tabular}

\subsubsection{Carboxymethylation}

Carboxymethylation pretreatment is one of the most prevalent pretreatment routes for the production of CNFs, where anionic carboxylate groups are introduced onto the cellulose fibers $[2,13,80,120-126]$. The attachment of negative charges provided by monochloroacetic acid through the controlled reaction condition (Figure 8A) creates an electrostatic repulsion that individualizes the cellulose fibers into cellulose fibrils in the following mechanical treatment process.

A

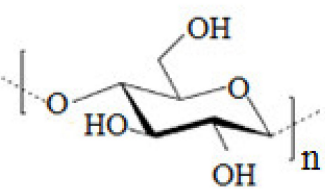

B

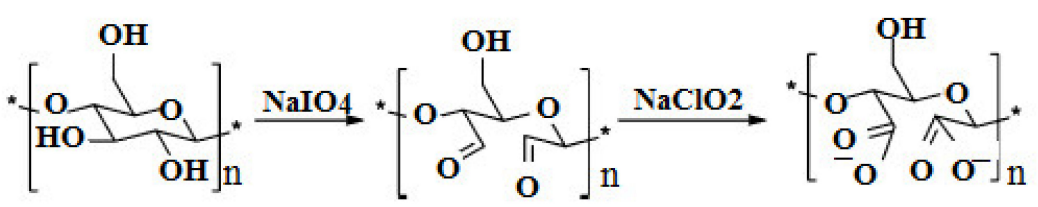

Figure 8. Carboxymethylation pretreatment of cellulose with monochloroacetic acid (A). Periodatechlorite sequential oxidation pretreatment of cellulose fibers (B).

Ankerfors et al. [101] estimated an electricity consumption of $2.33 \mathrm{kWh} / \mathrm{kg}$ for treatment through microfluidization after carboxymethylation pretreatment. Naderi et al. [18] introduced a novel protocol using different passing of cellulose fiber suspension at varying applied pressures of 400, 550, 850, and 1700 bar through the homogenizer. They concluded that this route led to more homogeneous and impressible fibrillation of cellulose fibers compared to one-time homogenization through HPM, which is currently accessible. In this regard, the energy consumption of cellulose fiber increased from 0.925 to $3.7 \mathrm{kWh} / \mathrm{kg}$ during one to four passes through the HPM at 400 bars. However, three passes of homogenization of cellulose fiber through HPH at 550 and 850 bar, and one step homogenization at 1700 bar required 3.8, 5.9, and $3.9 \mathrm{kWh} / \mathrm{kg}$, respectively [17]. Energy consumption of different cellulose nanofiber pretreatment systems such as enzyme and carboxymethyl pretreatments through microfluidizer (M-110EH, Microfluidics Corp., Westwood, MA, USA) was comprehensively studied by Naderi et al. [17] The energy consumption of enzymatically pretreated CNFs produced from sulfite dissolving pulp was shown to be $2.5 \mathrm{kWh} / \mathrm{kg}$ in comparison with carboxymethylated CNFs, which presented $2.4 \mathrm{kWh} / \mathrm{kg}$ at a similar passing (one passing) and the same consistency (2\%). It was postulated that enzymatically pretreated CNFs showed a lower degree of fibrillation and better barrier properties compared to carboxymethylated CNFs, while carboxymethylated CNFs displayed superior tensile strength, lower residual fiber fragment, and higher shear viscosity than enzymatically pretreated CNFs [17]. Conversely, according to a life cycle study by Arvidsson et al. [125], chemical pretreatment does not necessarily decrease the required energy consumption during the CNF preparation. The current study concluded that carboxymethylation pretreatment, due to the high input of chemicals such as ethanol, 
isopropanol, and methanol, addresses a higher cumulative energy demand compared to the homogenization approach only [125]. In this case, the environmental impacts of carboxymethylation pretreatment would be higher, albeit less mechanical energy usage is needed.

\subsubsection{Carboxymethyl Cellulose (CMC)-Modified Cellulose Fibers}

Irreversible attachment of CMC on cellulose fiber has initially been derived from its applications in paper [127-130]. Ankerfors et al. [101] was the first group to propose this pretreatment, and they examined three types of CMCs including one amphoteric and two anionic. The amphoteric CMC enabled high attachment level of up to $113 \mathrm{mg} / \mathrm{g}$ with charge densities of up to $231 \mu \mathrm{eq} / \mathrm{g}$. $\mu \mathrm{eq} / \mathrm{g}$. However, by using a low charged anionic $\mathrm{CMC}$, an attachment level of up to $62 \mathrm{mg} / \mathrm{g}$ was achieved. The mechanism behind the effect of CMC attachment as a pretreatment for cellulose nanofiber production was theoretically explained as follows. The CMC introduces charged groups that swell the fibers, however, it also serves as a lubricant for the fibers due to the electrostatic repulsion. The amphoteric CMC was more effective compared to anionic CMC in terms of lower CMC attached. It was concluded that the higher consistency of CMC-modified pulp resulted in lower energy consumption: CMC-modified pulp with $0.13 \%$ consistency consumed $36.3 \mathrm{kWh} / \mathrm{kg}$ for one passing and $181.5 \mathrm{kWh} / \mathrm{kg}$ for five passings through the HPH. However, increasing the initial consistency to $1.73 \%$ required 2.7 and $13.5 \mathrm{kWh} / \mathrm{kg}$ energy for one and five passing, respectively [18]. Naderi et al. [131] showed that negative charges produced on the fiber surface through carboxymethylation pretreatment resulted in an efficacious swelling of the fiber, and the fibrillation process was more effective than the enclosing of CMC on the cellulose fiber surfaces. Considering that the carboxymethylation pretreatment is required to be performed in a non-aqueous medium, (e.g., ethanol or isopropanol) to be efficient, the process is relatively complicated as several solvents must be applied and the solvent recovery is relatively pricy, and efficient delamination of fibers requires more energy. Therefore CMC-modified CNFs through an aqueous method, is potentially interesting for applications that do not require highly fibrillated CNFs such as a reinforcing agent in paper and cardboard materials, a rheology modifier in food products, and in the production of bio-based barrier materials [130].

\subsubsection{Periodate-Chlorite Oxidation}

Periodate-chlorite as a sequential regio-selective oxidation pretreatment has recently been performed for the production of CNFs. This pretreatment reduces the hydrogen bond by increasing the anionic charge density of cellulose fiber surfaces, thereby decreasing the required mechanical energy for the liberation of cellulosic fibers [61,85,132-136]. Briefly, cellulose fiber was mixed with $\mathrm{NaIO}_{4}$ at $55^{\circ} \mathrm{C}$, filtered and reacted with $\mathrm{NaClO}_{2}$ for two days at room temperature in $1 \mathrm{M}$ acetic acid. After adjusting the $\mathrm{pH}$ to 7.5 with sodium hydroxide, the cellulose suspension at $0.5 \mathrm{wt} \%$ was homogenized via one-to-four passes through a double chamber of HPF. As shown in Figure 8B, sodium meta-periodate oxidizes the hydroxyl groups of cellulose at positions 2 (C2) and 3 (C3) to produce aldehyde groups and subsequently oxidize the aldehyde groups to anionic carboxylate groups using sodium chlorite. Periodate-chlorite oxidation pretreatment converts aldehydes partially to anionic carboxylate groups. This would afterward promote the fibrillation of fibers and break the cellulose chains to some extent, despite its selectivity. Broken cellulose chains lead to a decrease in DP [134,136] and crystallinity of the cellulose fibers [61,137], which is desirable for reducing the energy consumption during the homogenization. Along this line, the DP of Pinus radiata market cellulose fiber pretreated with periodate oxidation pretreatment was reported to be $<70$. It was also shown that the highly oxidized cellulose fibers (carboxyl contents of 1.20 and $1.75 \mathrm{mmol} / \mathrm{g}$ ) after periodate oxidation presented a transparent appearance, whereas the samples with lower carboxyl contents maintained their fibrous structures. Previously, this type of pretreatment is followed by other reactions such as sulfonation $[138,139]$, reduction with sodium tetrahydridoborate [140,141], and metal salts 
(i.e., $\mathrm{LiCl}$ and $\mathrm{CaCl}_{2}$ ) as activators with milling treatment [132] for better fibrillation of different cellulose fibers. This type of pretreatment is very complex to implement in the industry despite all of its advantages and its applicability in different reactions.

\subsubsection{Emerging Pretreatments for Production of CNFs}

Phosphorylation

It is well known that introducing charged groups into cellulosic fibers reduces the strong cohesive forces among the fibrils, disrupts the cooperative hydrogen bonding [142-144], facilitates the fibrillation of pristine cellulose fibers, and subsequently decreases the energy consumption of the mechanical step and produces stable CNFs with excellent functional properties. Phosphorylation is currently categorized as one of the novel pretreatments, capable of providing negative charges on the cellulose fibers $[131,145,146]$ and subsequently establishing better fibrillation. Briefly, the cellulose fibers were impregnated with $\left(\mathrm{NH}_{4}\right)_{2} \mathrm{HPO}_{4}$ and urea at $1 \mathrm{wt} \%$, then filtered into $10 \mathrm{wt} \%$, dried at $70{ }^{\circ} \mathrm{C}$, and then cured at $150{ }^{\circ} \mathrm{C}$ for different durations. Interestingly, the phosphorylated CNFs prepared from passing 1-3 times through HPH at 1650 and 1700 bars were easily individualized to a cellulose fibril with $3 \mathrm{~nm}$ and $10 \mathrm{~nm}$, respectively. In addition, Noguchi et al. [146] prepared cellulose fibrils with 3-4 $\mathrm{nm}$ at $250 \mathrm{MPa}$ through Star Burst Labo. The corresponding prepared nanopapers demonstrated outstanding mechanical properties comparable to those of nanopapers prepared by Henriksson et al. [19]. The phosphate groups attached to the cellulose fibril surfaces provided a self-extinguishing behavior and improved thermal stability compared to those of the unmodified cellulose fibers. The prepared phosphorylated CNFs exhibited higher barrier performance and lowered oxygen permeability value (at $\mathrm{RH} 50 \%$ ) than the fibrillated CNFs (i.e., TEMPO-mediated oxidation-based CNFs and carboxymethylated $\mathrm{CNFs}$ ). It is noteworthy that the pretreatment, unlike other pretreatments, did not significantly change the intrinsic properties of CNFs such as viscosity-average DP and crystallinity index [146]. The nanopapers prepared from the phosphorylated CNFs showed extremely high transparency and represented a natural cellulose-based flame-retardant material. These unique characteristics of the phosphorylated cellulose nanopapers are promising for potential high value-added applications. Hence, this pretreatment proves that phosphorylated CNFs are able to establish a unique application of cellulose nanofiber, which is most interesting from an industrial point of view. Along this line, Oji Holding Corporation and Betulium applied this pretreatment as an attractive alternative to TEMPOmediated oxidation due to its easy implementation and non-toxic approach. It should be mentioned that there is no information regarding the mechanical energy consumption of this pretreatment in the literature.

\section{Sulfoethylation}

Sulfoethylation can be specified as an emerging pretreatment for the production of CNFs with more attractive characteristics compared to conventional ones. Naderi et al. [142] proposed a pretreatment process called the Michael reaction where never-dried cellulose fiber was dispersed in water at 10,000 revolutions using a laboratory pulper. The cellulose fiber (16 g dry mass) was soaked three times in 2-propanol (300 mL) using a kitchen blender and filtered off. The wet cellulose fiber was transferred into a flask, and then the solvent was exchanged with 2-propanol $(300 \mathrm{~mL})$. A solution of sodium hydroxide in half of the required amount of aqueous sodium vinyl sulfonate solution (VS, $25 \%(\mathrm{w} / \mathrm{w})$ was added dropwise at room temperature. The temperature increased to $80^{\circ} \mathrm{C}$, while stirring. After one hour, the remaining amount of VS was added to the mixture and stirring was continued for an additional three hours. The mixture was afterward poured into methanol, neutralized with acetic acid, washed with methanol/water $(70 / 30, \mathrm{v} / \mathrm{v})$, and filtered off. In the mentioned work, there was no need for any pretreatment such as periodate oxidation, which is often undesirable for CNF preparation, yet complicated in industrial implementation [87]. In another study, sulfoethylated CNFs were prepared by mechanical treatment via a microfluidizer (one pass at 1700 bar through two Z-shape 
$200 \mu \mathrm{m}$ and $100 \mu \mathrm{m}$ chambers). It was pointed out that this emerging pretreatment did not reduce DP, but crystallinity decreased from $61 \%$ to $41 \%$ [142]. Of interest to the conclusions is that this emerging pretreatment, due to the characteristics of its attached functional groups $\left(-\mathrm{CH}_{2} \mathrm{CH}_{2} \mathrm{SO}_{3}-\mathrm{Na}^{+}\right)$, exhibited superior properties such as better fibrillation, good-quality CNF lengths $(\leq 1 \mu \mathrm{m})$ and widths $(\approx 5 \mathrm{~nm})$, good dispersibility, higher stability at different $\mathrm{pH}$, and better water solubility compared to carboxymethylated CNFs. Additionally, the prepared nanopapers from sulfoethylated CNFs showed excellent barrier properties rather than the carboxymethylated CNFs.

\section{Deep Eutectic Solvent (DES)}

Deep eutectic solvents (DESs) have been proposed as an emerging pretreatment for the preparation of CNFs. Although DESs can be prepared through non-ionic species, they are often classified as ionic liquids (ILs). Generally, DESs are ambient temperature ionic liquids composed of two or three ionic compounds comprising of a hydrogen bond transferor (HBD) such as urea, glycerol, and ethylene glycol along with a hydrogen bond catcher (HBR) capable of combinations to form a eutectic mixture $[147,148]$. A lower melting point of DESs than each individual component is a peculiar property as the strong hydrogen bonding prevents crystallization of parent components [149]. DESs possess similar physicochemical properties in comparison to ILs, however, they are considered as an inexpensive, eco-friendly, biodegradable, and green solvent with relatively low toxicity [150-152]. Recently, various urea-based DESs including choline chloride (ChCl) [152-154], ammonium thiocyanate, or guanidine hydrochloride [149] have been successfully employed for the pretreatment of cellulose for the production of CNFs. For example, Suopajärvi et al. [151] pretreated $25 \mathrm{~g}$ of different secondary cellulose fibers at a consistency of $\sim 30 \%$ with the DESs solution (choline chloride and urea). They mixed the components for two hours at $100{ }^{\circ} \mathrm{C}$, washed the ensuing suspension, and used a Masuko super masscolloider MKCA6-2J (Kawaguchi, Japan) grinder (consistency of $1.5 \%$ ) or a Microfluidics M-110EH-30 (Westwood, MA, USA) microfluidizer to obtain CNFs (consistency of $0.4 \%$ ) through various chambers, passes, and pressures of high-pressure homogenization. The homogenized pulp had a gel-like appearance with shear thinning behavior and a web-like nanofibrous structure. Although it was concluded that the mechanism behind the DESs reaction with cellulose was unknown, Sirviö et al. [153] theorized that the DESs solvent could penetrate the cellulose fibers and loosen their structure, allowing for more efficient fibrillation. They also proposed a possible assumption that a small number of hydroxyl groups are converted to carbamates, which led to an extent, to a similar distortion of the hydrogen bonding network such as TEMPO-mediated oxidation or carboxymethylation [153]. More recently, Tenhunen et al. [152] suggested that cationic choline ions interacted with the anionic groups of cellulose fibers via electrostatic interactions. In this context, Table 6 summarizes different DESs applied for pretreatment of cellulose and corresponding CNF characteristics.

Cellulose fibers were observed to disintegrate into cellulose nanofibrils with widths of 2-21 nm during the DESs pretreatment. In this context, the fiber morphology had not been altered, and negligible changes were noted in the carbohydrate composition [152,153]. These findings suggest that the used DES systems were capable of swelling and loosening the fiber macroscopic structural integrity without notable degradation of the molecular cellulose chain structure. One limiting factor in the DES system, in light of all the concluded advantages, is the prolonged reaction time for choline chloride and urea $\left(16 \mathrm{~h}\right.$ at $100{ }^{\circ} \mathrm{C}[152]$, $15 \mathrm{~h}$ at $90^{\circ} \mathrm{C}$ with sodium hydroxide [150], and $2 \mathrm{~h}$ at $100^{\circ} \mathrm{C}$ [151]). Overall, from Table 6, it can be observed that this novel pretreatment does not significantly decrease the fibers' DP and leads to CNFs with acceptable transmittance. DESs are classified as a non-hydrolytic pretreatment that can enhance the fibrillation of cellulose fibers and are also categorized as a green, easy-to-use, inexpensive, and recyclable pretreatment; however, their use still requires further research. There is no comprehensive information regarding the advantage 
of this pretreatment on energy consumption during the mechanical treatment for the production of $\mathrm{CNFs}$ in the relevant literature.

Table 6. Different DESs used for the pretreatment of cellulose and corresponding CNF characteristics.

\begin{tabular}{|c|c|c|c|c|c|c|}
\hline \multirow{2}{*}{ Pristine Fibers } & \multirow{2}{*}{$\begin{array}{l}\text { DESs System } \\
\text { Used }\end{array}$} & \multirow{2}{*}{$\begin{array}{c}\text { Applied } \\
\text { Mechanical } \\
\text { Treatment }\end{array}$} & \multicolumn{3}{|c|}{ CNF Properties } & \multirow{2}{*}{ References } \\
\hline & & & $\begin{array}{l}\text { Diameter } \\
(\mathrm{nm})\end{array}$ & DP & Crystallinity(\%) & \\
\hline $\begin{array}{l}\text { Bleached birch pulp } \\
\text { (Betula pendula) }\end{array}$ & $\begin{array}{l}\text { Choline chloride } \\
\text { and urea }\end{array}$ & Microfluidizer & $2-5$ & No change & No change & [45] \\
\hline $\begin{array}{l}\text { Bleached birch pulp } \\
\text { (Betula pendula) }\end{array}$ & $\begin{array}{c}\text { Ammonium } \\
\text { thiocyanate and } \\
\text { urea }\end{array}$ & Microfluidizer & $10.7-21.4$ & 3337 & - & [48] \\
\hline $\begin{array}{l}\text { Bleached birch pulp } \\
\text { (Betula pendula) }\end{array}$ & $\begin{array}{c}\text { Guanidine } \\
\text { hydrochloride and } \\
\text { urea }\end{array}$ & Microfluidizer & $11.5-15.8$ & 3315 & - & [48] \\
\hline $\begin{array}{c}\text { Commercial } \\
\text { softwood } \\
\text { dissolving pulp }\end{array}$ & $\begin{array}{l}\text { Lithium chloride } \\
\text { and urea }\end{array}$ & Microfluidizer & $2-7$ & $1646-1676$ & 10-18\% Drop & [49] \\
\hline $\begin{array}{l}\text { Waste board (WB) } \\
\text { and milk container } \\
\text { board }(\mathrm{MCB})\end{array}$ & $\begin{array}{l}\text { Choline chloride } \\
\text { and urea }\end{array}$ & $\begin{array}{l}\text { Masuku grinder } \\
\text { Microfluidizer }\end{array}$ & $2-80$ & - & $47-61$ & {$[46]$} \\
\hline
\end{tabular}

\subsubsection{Other Pretreatments}

Ozone

Some unconventional pretreatments can also be applied to cellulosic fibers for the production of CNFs. Ozone gas, along with syringic acid, was used to enhance the oxidation reactions of enzymatic pretreated cellulose fibers [155]. Briefly, syringic acid powder $(0.25 \mathrm{~g})$ was mixed with $150 \mathrm{~mL}$ of $1 \% \mathrm{w} / \mathrm{v}$ enzyme-treated pulp, and the $\mathrm{pH}$ of the resultant solution was increased to 11 using $1 \mathrm{M} \mathrm{NaOH}$ to enhance the reactivity of the cellulose hydroxyl groups. Ozone-containing gas was subsequently exerted at a flow rate of $0.25 \mathrm{l} / \mathrm{min}$ with a concentration of $18 \mathrm{mg} / 1(1.26 \mathrm{wt} . \%)$. The pulp suspension was persistently stirred on a stir plate, and in a fume hood at room temperature $\left(20^{\circ} \mathrm{C}\right)$. The efficiency of the current pretreatment was compared to the conventional TEMPO-mediated oxidation process. It was found that ozone oxidation accompanies by a lignin-derived phenolic (syringic acid) could be nominated as an alternative to TEMPO-mediated oxidation of the cellulose surface to produce CNFs [155]. The ozone gas alone was not able to oxidize the cellulose fiber surface through reaction with free hydroxyl groups, but the hydroxyl radicals can also form during the reaction of ozone along with syringic acid with cellulose fibers. Similar to TEMPO-mediated oxidation, these radicals relatively oxidized the primary alcohol located on the $\mathrm{C} 6$ of the glucose ring to stable carboxylate groups. Interestingly, in contrast to TEMPO-mediated oxidation, syringic acid can be described as a natural oxidant degraded during the oxidation reaction. The CNFs morphology prepared from this extraordinary pretreatment was explored to be $3-10 \mathrm{~nm}$ widths and lengths $>100 \mathrm{~nm}$ after ultra-sonication of the oxidized product in an aqueous suspension. The prepared cellulose nanofibers through this pretreatment had a carboxylate content such as conventional carboxylated cellulose prepared by TEMPO-mediated oxidation.

\section{Fenton Pretreatment}

Fenton pretreatment is defined as an acidic hydrogen peroxide pretreatment in the presence of ferrous ions (Fenton's reagent). Fenton oxidation is a reaction of ferrous ion $\left(\mathrm{Fe}^{2+}\right)$, catalyzing hydrogen peroxide $\left(\mathrm{H}_{2} \mathrm{O}_{2}\right)$ to produce hydroxyl radicals (HO-). Hydroxyl radicals, as a strong oxidant, can oxidize and degrade organic polymers such as cellulose. It results in an increase in total charge and number of carbonyl groups, lowering intrinsic viscosity [23]. Accordingly, the Fenton pretreated cellulosic fibers are easier to homogenize 
compared to enzymatic pretreatment (i.e., lower viscosity $\left(190-280 \mathrm{dm}^{3} / \mathrm{kg}\right.$ ) and DP (450-660), higher surface area charge, and higher carbonyl content (79-105 $\mu \mathrm{mol} / \mathrm{g})$ ) at a constant homogenization time. It was shown that the Fenton pretreatment yielded a higher degree of fibrillation compared to enzymatic pretreatment for the preparation of MFC after similar passes through the pilot plant HPH. In addition, Fenton pretreatment eventuated in slightly lower energy after 2-5 passes through the HPH. In fact, the energy required for five passes through HPH was reported to be $10 \mathrm{kWh} / \mathrm{kg}$ for Fenton pretreatment and $12 \mathrm{kWh} / \mathrm{kg}$ for endoglucanase enzymatic pretreatment [156]. Therefore, this eco-friendly pretreatment is considered as a promising alternative to enzymatic pretreatment for the preparation of MFC. It can also provide an opportunity to introduce an energy-efficient pretreatment to achieve a better quality of MFC in terms of the number of fibril elements.

Oxone ${ }^{\circledR}$ Pretreatment

The Oxone ${ }^{\circledR}$ pretreatment was recently accredited as a novel, green, and one-pot oxidant pretreatment for cellulose pulp fibers [157,158]. In general, Oxone ${ }^{\circledR}$ is the trade name of the stable triple salts with the composition of $2 \mathrm{KHSO}_{5} \cdot \mathrm{KHSO}_{4} \cdot \mathrm{K}_{2} \mathrm{SO}_{4}$. The active component potassium monopersulfate $\left(\mathrm{KHSO}_{5}\right.$, potassium peroxomonosulfate) is salt from Caro's acid $\mathrm{H}_{2} \mathrm{SO}_{5}$. The use of Oxone ${ }^{\circledR}$ has rapidly increased, thanks to its stability, simple handling, non-toxic nature, the versatility of the reagent, and the low cost. It was recently found that Oxone ${ }^{\circledR}$ oxidation pretreatment could potentially be substituted with TEMPO-mediated oxidation pretreatment due to existing impediments of TEMPO-mediated oxidation pretreatment such as toxic side products (halogen-containing, co-oxidants), contamination of final products (risk of having trace amounts of reactive radicals in the product), higher cost, and complexity for industrial applications $[159,160]$. Ruan et al. $[157,158]$ employed Oxone ${ }^{\circledR}$ pretreatment, where $2 \mathrm{~g}$ of never-dried cellulose fiber was dispersed in $40 \mathrm{~mL}$ deionized water using high-energy ultrasonication. The dispersed cellulose fiber was then incorporated into a round-bottom flask containing $9.1 \mathrm{~g}$ Oxone ${ }^{\circledR}$ (2.4 equivalents per anhydroglucose unit) pre-dissolved in $10 \mathrm{~mL}$ deionized water. The Oxone ${ }^{\circledR}$ oxidation pretreatment reaction was executed at $80{ }^{\circ} \mathrm{C}$ under stirring. After $24 \mathrm{~h}$, the Oxone ${ }^{\circledR}$-oxidized cellulose fibers were thoroughly washed with deionized water by filtration. It was explored that Oxone ${ }^{\circledR}$ introduced anionic groups on the surface of cellulose fibers through selectively oxidizing the C6 hydroxyl groups of cellulose to carboxylic groups $[157,158]$. Although Oxone ${ }^{\circledR}$ pretreatment represented a lower carboxyl content $(1.073 \mathrm{mmol} / \mathrm{gr})$ of softwood sulfite bleached cellulose fibers than TEMPO-mediated oxidation, the oxidized cellulose fibers could be easily disintegrated. Hence, it means that less mechanical treatment is required to obtain a certain degree of dispersion. It can interestingly be concluded that pretreatment with Oxone ${ }^{\circledR}$ oxidation creates a mechanical fibrillation process that is more efficient and low energy-demanding, however, it undesirably decreases the aspect ratio of the CNFs. The prepared CNFs with this pretreatment had a diameter of about $10 \mathrm{~nm}$, while unpretreated pulp presented CNFs with a diameter of about $50 \mathrm{~nm}$. The lengths of these individualized CNFs were explored to be a few hundred nm.

\section{Commercialization and Challenges}

Over the last few years, we have witnessed a worldwide emergence of enterprises, focusing on the production and commercialization of CNFs. Cellulose nanofibers are being produced at different facilities such as industrial, pilot, and lab scales due to its extraordinary properties and pivotal role in the development of a bioeconomy in forest product industries. Table 7 represents a recent list of defined facilities for the production of CNFs worldwide. However, we believe that there are numerous unreported lab scale facilities at universities, research centers, paper mills, and other sites that have not been included in Table 7. Based on the information cited in Table 7, the total capacity to produce CNFs was estimated to be 163 tons/day. Nevertheless, academic and industrial sectors are still clamoring for new pathways toward the scaling up of CNF production and the 
steep rise in demand to develop sustainable materials in various applications support the need to produce cost-effective CNFs to compete with existing low-cost materials. Diversity in the raw material structures is one of the biggest challenges in reaching a unique method for CNF production. Generally, the chemical composition of the raw materials is species-dependent, and even for a specific plant species, it depends on various factors. Amending the production methods to keep the consistency among the CNF properties from one batch to another result in less rejection in the final product, driving down the final price. The utilization of non-wood species for CNF production is a way to reduce the costs. As mentioned earlier, the production of $\mathrm{CNFs}$ mostly required pretreatment approaches and stages. Implementation of new protocols, specifically the one-pot production methods to reduce the chemicals, equipment, and time, would decrease the production costs. Part of the costs can be also decreased either by the development of the existing functionalization methods aiming to increase the charge density of fibers, or by introducing the less aggressive chemicals and more straightforward and green strategies. Inventing new approaches to overcome the clogging issues in the equipment is also a necessity. Finally, finding a major application that needs a large quantity of CNFs is also required for making CNFs industrially worthwhile.

Table 7. Most recent list of implemented facilities for the commercial production of CNFs globally.

\begin{tabular}{|c|c|c|}
\hline $\begin{array}{c}\text { The Commercial Name of } \\
\text { Facility }\end{array}$ & Country Located & $\begin{array}{l}\text { Capacity } \\
\text { Tons/Year }\end{array}$ \\
\hline Kruger Biomaterials Inc. & Canada & 6000 \\
\hline Domtar & Canada & $50-75$ tons / day \\
\hline American Process Inc. & USA & 100 \\
\hline $\begin{array}{l}\text { University of Maine, Process } \\
\text { Development Center }\end{array}$ & USA & 1 ton/day \\
\hline $\begin{array}{l}\text { Turners Falls Paper, } \\
\text { Paperlogic }\end{array}$ & USA & 2 tons/day \\
\hline Fibria & Brazil & 2 tons/day \\
\hline Suzano & Brazil & $50 \mathrm{~kg} /$ day \\
\hline Borregaard & Norway & 1000 \\
\hline Norsk Skog & Norway & 1 ton/day \\
\hline RISE Bioeconomy & Sweden & 1 ton/day \\
\hline Stora Enso Ltd. & Sweden & Industrial \\
\hline UPM-Kymmene Ltd. & Sweden/Finland & Pilot scale \\
\hline VTT & Finland & Semi-pilot \\
\hline CelloComp & UK & 400 \\
\hline Fiber Lean Technologies & UK & 8000 \\
\hline InTechFibers & France & $100 \mathrm{~kg} /$ day \\
\hline SAPPI & Netherland & 8 \\
\hline WEIDMANN & Switzerland & 500 \\
\hline DKS Co., Ltd. & Japan & 50 \\
\hline Daio Paper Corp. & Japan & 100 \\
\hline $\begin{array}{l}\text { Chuetsu Pulp \& Paper Co. } \\
\text { Ltd. }\end{array}$ & Japan & 100 \\
\hline Nippon Paper Group & Japan & 500 \\
\hline Oji Holdings Corporation & Japan & 40 \\
\hline
\end{tabular}




\section{Conclusions and Future Remarks}

Cellulose nanofibers (CNFs) are considered as a new bionanomaterial with outstanding intrinsic properties. Due to their properties such as renewability, biocompatibility, and biodegradability, they have abundant applications, more particularly in value-added biomaterials. Although there are numerous operating commercial and pilot plants, $\mathrm{CNF}$ and LCNF utilization are still limited, mainly due to high initial investment and production costs, and high mechanical energy demands. This review paper, for the first time, addresses the recent trends and most applied routes of energy-efficient and eco-friendly processes in the production of different $\mathrm{CN}$ qualities from low-cost raw materials, with efficient pretreatments and mechanical processes. In order to overcome the available obstacles in making CNFs commercially competitive, new strategies including the use of low-cost raw materials, effective chemical and enzymatic pretreatments, and appropriate selection of final mechanical processes were discussed. Therefore, an update of the most relevant processes and energy-efficient mechanical approaches for low-cost CNFs and LCNFs were practically outlined.

Author Contributions: Conceptualization, S.R.D.P.; Investigation, S.R.D.P.; Writing-original draft, S.R.D.P.; Supervision, S.R.D.P.; Project administration, S.R.D.P.; Critically revising the manuscript, S.R.D.P.; Writing-review and editing, S.R.D.P., B.C., E.L., M.N., J.S., S.G., B.A., J.H., and S.T. All authors have read and agreed to the published version of the manuscript.

Funding: This research received no external funding.

Institutional Review Board Statement: Not applicable.

Informed Consent Statement: Not applicable.

Conflicts of Interest: The authors declare that they have no known competing financial interests or personal relationships that could have appeared to influence the work reported in this paper.

\section{Nomenclature}

$\begin{array}{ll}\text { ACC } & \text { All cellulose composites } \\ \text { AQ } & \text { Anthraquinone } \\ \text { BKHW } & \text { Bleached kraft hardwood pulp } \\ \mathrm{CMC} & \text { Carboxymethyl cellulose } \\ \mathrm{COO}^{-} & \text {Carboxylate group } \\ \mathrm{CaCl}_{2} & \text { Calcium chloride } \\ \mathrm{CNFs}_{\mathrm{CTMP}} & \text { Cellulose nanofibers } \\ \mathrm{CNCs} & \text { Chemithermo mechanical pulp } \\ \mathrm{CMP} & \text { Cellulose nanocrystals } \\ \mathrm{ChCl} & \text { Chemi-mechanical pulp } \\ \mathrm{DPFS} & \text { Choline chloride } \\ \mathrm{DESs} & \text { Date palm fruit stalks } \\ \mathrm{DP} & \text { Deep eutectic solvents } \\ \mathrm{NH} & 2 \mathrm{HPO} \\ \mathrm{PSNFD} & \text { Degree of polymerization } \\ \mathrm{EFB} & \text { Diammonium hydrogen phosphate } \\ \mathrm{EPFBF} & \text { Dried paper sludge nanofibers } \\ \mathrm{FESEM} & \text { Empty fruit bunches } \\ \mathrm{HPHs} & \text { Empty palm fruit bunch fibers } \\ \mathrm{HPMs} & \text { Field emission electron scanning microscopy } \\ \mathrm{HBD} & \text { High pressure homogenizers } \\ \mathrm{HBR} & \text { High pressure microfluidizers } \\ \mathrm{H}_{2} \mathrm{O}{ }_{2} & \text { Hydrogen bond transferor } \\ \mathrm{OH} & \text { Hydrogen bond catcher } \\ \mathrm{KWh} / \mathrm{Kg} & \text { Hydrogen peroxide } \\ & \text { Kydroxyl group } \\ & \text { Kilowatt-hour per kilogram }\end{array}$




$\begin{array}{ll}\text { LCNFs } & \text { Lignocellulosic nanofibers } \\ \text { LNPs } & \text { Lignin nanoparticles } \\ \text { LiCl } & \text { Lithium chloride } \\ \text { LPMO } & \text { Lytic polysaccharide monooxygenase } \\ \text { MKCA6-2J } & \text { Masuko super masscolloider } \\ \text { MPa) } & \text { Megapascal } \\ \text { MFA } & \text { Microfibril angle } \\ \text { MFC } & \text { Micro-fibrillated cellulose } \\ \mu \text { mol/g } & \text { Micromol per gram } \\ \mu \text { eq. /g } & \text { Microequivalent per gram } \\ \text { MCB } & \text { Milk container board } \\ \text { MOP } & \text { Mixed office paper } \\ \text { MSWP } & \text { Municipal solid waste paper } \\ \text { PSNFND } & \text { Never-dried paper sludge nanofibers } \\ \text { NSSC } & \text { Neutral sulfite semichemical } \\ \text { nm } & \text { Nanometer } \\ \text { OCC } & \text { Old corrugated container } \\ \text { PSNF } & \text { Paper sludge nanofibers } \\ \text { Ph-GH5 } & \text { Purified and commercial Endoglucanase } \\ \text { RN } & \text { Recycled newsprint } \\ \text { RH } & \text { Relative humidity } \\ \text { SiC } & \text { Silicon carbide } \\ \text { G' } & \text { Storage modulus } \\ \text { VTT } & \text { Technical Research Centre of Finland } \\ \text { TEMPO } & \text { 2,2,6,6-Tetramethylpiperidin-1-yl)oxyl } \\ \text { TSE } & \text { Twin screw extruder } \\ \text { VS } & \text { Vinyl sulfonate solution } \\ \text { WB } & \text { Waste board } \\ & \end{array}$

\section{References}

1. Klemm, D.; Heublein, B.; Fink, H.-P.; Bohn, A. Cellulose: Fascinating Biopolymer and Sustainable Raw Material. Angew. Chem. Int. Ed. 2005, 44, 3358-3393. [CrossRef] [PubMed]

2. Siró, I.; Plackett, D. Microfibrillated cellulose and new nanocomposite materials: A review. Cellulose 2010, 17, 459-494. [CrossRef]

3. Khalil, H.A.; Davoudpour, Y.; Saurabh, C.; Hossain, S.; Adnan, A.S.; Dungani, R.; Paridah, M.; Sarker, Z.I.; Fazita, M.N.; Syakir, M.; et al. A review on nanocellulosic fibres as new material for sustainable packaging: Process and applications. Renew. Sustain. Energy Rev. 2016, 64, 823-836. [CrossRef]

4. Bina, B.; Azadbakht, P.; Pourzamani, H.; Petroudy, S.R.J. Removal of nitrate from aqueous solution using nanocrystalline cellulose. Int. J. Environ. Health Eng. 2016, 5, 17. [CrossRef]

5. Petroudy, S.R.D.; Syverud, K.; Chinga-Carrasco, G.; Ghasemain, A.; Resalati, H. Effects of bagasse microfibrillated cellulose and cationic polyacrylamide on key properties of bagasse paper. Carbohydr. Polym. 2014, 99, 311-318. [CrossRef] [PubMed]

6. Chen, Y.; Fan, D.; Han, Y.; Lyu, S.; Lu, Y.; Li, G.; Jiang, F.; Wang, S. Effect of high residual lignin on the properties of cellulose nanofibrils/films. Cellulose 2018, 25, 6421-6431. [CrossRef]

7. Winter, A.; Andorfer, L.; Herzele, S.; Zimmermann, T.; Saake, B.; Edler, M.; Griesser, T.; Konnerth, J.; Gindl-Altmutter, W. Reduced polarity and improved dispersion of microfibrillated cellulose in poly(lactic-acid) provided by residual lignin and hemicellulose. J. Mater. Sci. 2016, 52, 60-72. [CrossRef]

8. Petroudy, S.R.D.; Kahagh, S.A.; Vatankhah, E. Environmentally friendly superabsorbent fibers based on electrospun cellulose nanofibers extracted from wheat straw. Carbohydr. Polym. 2021, 251, 117087. [CrossRef]

9. Petroudy, S.R.D.; Ghasemian, A.; Resalati, H.; Syverud, K.; Chinga-Carrasco, G. The effect of xylan on the fibrillation efficiency of DED bleached soda bagasse pulp and on nanopaper characteristics. Cellulose 2014, 22, 385-395. [CrossRef]

10. Solala, I.; Volperts, A.; Andersone, A.; Dizhbite, T.; Mironova-Ulmane, N.; Vehniäinen, A.; Pere, J.; Vuorinen, T. Mechanoradical formation and its effects on birch kraft pulp during the preparation of nanofibrillated cellulose with Masuko refining. Holzforschung 2012, 66, 477-483. [CrossRef]

11. Pennells, J.; Godwin, I.D.; Amiralian, N.; Martin, D.J. Trends in the production of cellulose nanofibers from non-wood sources. Cellulose 2019, 27, 575-593. [CrossRef]

12. Isogai, A.; Saito, T.; Fukuzumi, H. TEMPO-oxidized cellulose nanofibers. Nanoscale 2011, 3, 71-85. [CrossRef]

13. Lindstrom, T.; Naderi, A.; Wiberg, A. Large Scale Applications of Nanocellulosic Materials-A Comprehensive Review. J. Korea Tech. Assoc. Pulp Pap. Ind. 2015, 47, 5-21. [CrossRef]

14. Zimmermann, T.; Bordeanu, N.; Strub, E. Properties of nanofibrillated cellulose from different raw materials and its reinforcement potential. Carbohydr. Polym. 2010, 79, 1086-1093. [CrossRef] 
15. Spence, K.L.; Venditti, R.A.; Rojas, O.J.; Habibi, Y.; Pawlak, J.J. A comparative study of energy consumption and physical properties of microfibrillated cellulose produced by different processing methods. Cellulose 2011, 18, 1097-1111. [CrossRef]

16. Tejado, A.; Alam, N.; Antal, M.; Yang, H.; Van De Ven, T.G.M. Energy requirements for the disintegration of cellulose fibers into cellulose nanofibers. Cellulose 2012, 19, 831-842. [CrossRef]

17. Naderi, A.; Lindström, T.; Sundström, J. Repeated homogenization, a route for decreasing the energy consumption in the manufacturing process of carboxymethylated nanofibrillated cellulose? Cellulose 2015, 22, 1147-1157. [CrossRef]

18. Naderi, A.; Lindström, T.; Sundström, J.; Pettersson, T.; Flodberg, G.; Erlandsson, J. Microfluidized carboxymethyl cellulose modified pulp: A nanofibrillated cellulose system with some attractive properties. Cellulose 2015, 22, 1159-1173. [CrossRef]

19. Henriksson, M.; Berglund, L.; Isaksson, P.; Lindström, T.; Nishino, T. Cellulose Nanopaper Structures of High Toughness. Biomacromolecules 2008, 9, 1579-1585. [CrossRef]

20. Petroudy, S.D. Physical and Mechanical Properties of Natural Fibers; Elsevier BV: Amsterdam, The Netherlands, $2017 ;$ pp. 59-83.

21. Jonoobi, M.; Oladi, R.; Davoudpour, Y.; Oksman, K.; Dufresne, A.; Hamzeh, Y.; Davoodi, R. Different preparation methods and properties of nanostructured cellulose from various natural resources and residues: A review. Cellulose 2015, 22, 935-969. [CrossRef]

22. Hassan, M.; Berglund, L.; Hassan, E.; Abou-Zeid, R.; Oksman, K. Effect of xylanase pretreatment of rice straw unbleached soda and neutral sulfite pulps on isolation of nanofibers and their properties. Cellulose 2018, 25, 2939-2953. [CrossRef]

23. Song, Y.; Jiang, W.; Zhang, Y.; Ben, H.; Han, G.; Ragauskas, A.J. Isolation and characterization of cellulosic fibers from kenaf bast using steam explosion and Fenton oxidation treatment. Cellulose 2018, 25, 4979-4992. [CrossRef]

24. Ferrer, A.; Filpponen, I.; Rodríguez, A.; Laine, J.; Rojas, O. Valorization of residual Empty Palm Fruit Bunch Fibers (EPFBF) by microfluidization: Production of nanofibrillated cellulose and EPFBF nanopaper. Bioresour. Technol. 2012, 125, 249-255. [CrossRef] [PubMed]

25. Hassan, M.; Bras, J.; Hassan, E.; Silard, C.; Mauret, E. Enzyme-assisted isolation of microfibrillated cellulose from date palm fruit stalks. Ind. Crop. Prod. 2014, 55, 102-108. [CrossRef]

26. Josset, S.; Orsolini, P.; Siqueira, G.; Tejado, A.; Tingaut, P.; Zimmermann, T. Energy consumption of the nanofibrillation of bleached pulp, wheat straw and recycled newspaper through a grinding process. Nord. Pulp Pap. Res. J. 2014, 29, 167-175. [CrossRef]

27. Suopajärvi, T.; Liimatainen, H.; Niinimäki, J. Morphological Analyses of Some Micro- and Nanofibrils from Birch and Wheat Straw Sources. J. Wood Chem. Technol. 2014, 35, 102-112. [CrossRef]

28. Dufresne, A.; Cavaillé, J.Y.; Vignon, M.R. Mechanical behavior of sheets prepared from sugar beet cellulose microfibrils. J. Appl. Polym. Sci. 1997, 64, 1185-1194. [CrossRef]

29. Alemdar, A.; Sain, M. Isolation and characterization of nanofibers from agricultural residues-Wheat straw and soy hulls. Bioresour. Technol. 2008, 99, 1664-1671. [CrossRef]

30. Zuluaga, R.; Putaux, J.L.; Cruz, J.; Vélez, J.; Mondragon, I.; Gañán, P. Cellulose microfibrils from banana rachis: Effect of alkaline treatments on structural and morphological features. Carbohydr. Polym. 2009, 76, 51-59. [CrossRef]

31. Jonoobi, M.; Harun, J.; Shakeri, A.; Misra, M.; Oksmand, K. Chemical composition, crystallinity, and thermal degradation of bleached and unbleached kenaf bast (Hibiscus cannabinus) pulp and nanofibers. BioResources 2009, 4, 626-639. [CrossRef]

32. Jonoobi, M.; Harun, J.; Tahir, P.M.; Zaini, L.H.; SaifulAzry, S.; Makinejad, M.D. Characteristics of nanofibers extracted from kenaf core. BioResources 2010, 5, 2556-2566. [CrossRef]

33. Jonoobi, M.; Mathew, A.P.; Oksman, K. Producing low-cost cellulose nanofiber from sludge as new source of raw materials. Ind. Crop. Prod. 2012, 40, 232-238. [CrossRef]

34. Hassan, M.L.; Mathew, A.P.; Hassan, E.A.; El-Wakil, N.A.; Oksman, K. Nanofibers from bagasse and rice straw: Process optimization and properties. Wood Sci. Technol. 2012, 46, 193-205. [CrossRef]

35. Charani, P.R.; Dehghani-Firouzabadi, M.; Afra, E.; Shakeri, A. Rheological characterization of high concentrated MFC gel from kenaf unbleached pulp. Cellulose 2013, 20, 727-740. [CrossRef]

36. Xiao, S.; Gao, R.; Gao, L.; Li, J. Poly(vinyl alcohol) films reinforced with nanofibrillated cellulose (NFC) isolated from corn husk by high intensity ultrasonication. Carbohydr. Polym. 2016, 136, 1027-1034. [CrossRef] [PubMed]

37. Boufi, S.; Gandini, A. Triticale crop residue: A cheap material for high performance nanofibrillated cellulose. RSC Adv. 2015, 5, 3141-3151. [CrossRef]

38. Liu, X.; Jiang, Y.; Qin, C.; Yang, S.; Song, X.; Wang, S.; Li, K. Enzyme-assisted mechanical grinding for cellulose nanofibers from bagasse: Energy consumption and nanofiber characteristics. Cellulose 2018, 25, 7065-7078. [CrossRef]

39. Mohammed, B.S.; Fang, O.C. Assessing the properties of freshly mixed concrete containing paper-mill residuals and class F fly ash. J. Civ. Eng. Constr. Technol. 2011, 2, 17-26.

40. De Alda, J.A.G.O. Feasibility of recycling pulp and paper mill sludge in the paper and board industries. Resour. Conserv. Recycl. 2008, 52, 965-972. [CrossRef]

41. Migneault, S.; Koubaa, A.; Riedl, B.; Nadji, H.; Deng, J.; Zhang, S.Y. Binderless fiberboard made from primary and secondary pulp and paper sludge. Wood Fiber Sci. 2011, 43, 180-193.

42. Koubaa, A.; Riedl, B. Medium-density fiberboard produced using pulp and paper sludge from different pulping processes. Wood Fiber Sci. 2010, 42, 1-12.

43. Leao, A.; Cherian, B.M.; De Souza, S.F.; Sain, M.; Narine, S.; Caldeira, M.S.; Toledo, M.A.S. Use of Primary Sludge from Pulp and Paper Mills for Nanocomposites. Mol. Cryst. Liq. Cryst. 2012, 556, 254-263. [CrossRef] 
44. Adu, C.; Berglund, L.; Oksman, K.; Eichhorn, S.J.; Jolly, M.; Zhu, C. Properties of cellulose nanofibre networks prepared from never-dried and dried paper mill sludge. J. Clean. Prod. 2018, 197, 765-771. [CrossRef]

45. Young, R.A. Comparison of the properties of chemical cellulose pulps. Cellulose 1994, 1, 107-130. [CrossRef]

46. Spinu, M.; Dos Santos, N.; Le Moigne, N.; Navard, P. How does the never-dried state influence the swelling and dissolution of cellulose fibres in aqueous solvent? Cellulose 2010, 18, 247-256. [CrossRef]

47. Hietala, M.; Varrio, K.; Berglund, L.; Soini, J.; Oksman, K. Potential of municipal solid waste paper as raw material for production of cellulose nanofibres. Waste Manag. 2018, 80,319-326. [CrossRef]

48. Danial, W.H.; Majid, Z.A.; Muhid, M.N.M.; Triwahyono, S.; Bakar, M.B.; Ramli, Z. The reuse of wastepaper for the extraction of cellulose nanocrystals. Carbohydr. Polym. 2015, 118, 165-169. [CrossRef]

49. Wang, H.; Li, D.; Zhang, R. Preparation of Ultralong Cellulose Nanofibers and Optically Transparent Nanopapers Derived from Waste Corrugated Paper Pulp. BioResources 2012, 8, 1374-1384. [CrossRef]

50. Wang, Q.; Zhu, J. Facile preparation of nanofiller-paper using mixed office paper without deinking. Tappi J. 2015, 14, 167-174. [CrossRef]

51. Iwamoto, S.; Abe, K.; Yano, H. The Effect of Hemicelluloses on Wood Pulp Nanofibrillation and Nanofiber Network Characteristics. Biomacromolecules 2008, 9, 1022-1026. [CrossRef] [PubMed]

52. Iwamoto, S.; Kai, W.; Isogai, T.; Saito, T.; Isogai, A.; Iwata, T. Comparison study of TEMPO-analogous compounds on oxidation efficiency of wood cellulose for preparation of cellulose nanofibrils. Polym. Degrad. Stab. 2010, 95, 1394-1398. [CrossRef]

53. Chaker, A.; Alila, S.; Mutjé, P.; Vilar, M.R.; Boufi, S. Key role of the hemicellulose content and the cell morphology on the nanofibrillation effectiveness of cellulose pulps. Cellulose 2013, 20, 2863-2875. [CrossRef]

54. Chaker, A.; Mutjé, P.; Vilar, M.R.; Boufi, S. Agriculture crop residues as a source for the production of nanofibrillated cellulose with low energy demand. Cellulose 2014, 21, 4247-4259. [CrossRef]

55. Spence, K.L.; Venditti, R.A.; Habibi, Y.; Rojas, O.; Pawlak, J.J. The effect of chemical composition on microfibrillar cellulose films from wood pulps: Mechanical processing and physical properties. Bioresour. Technol. 2010, 101, 5961-5968. [CrossRef] [PubMed]

56. Osong, S.H.; Norgren, S.; Engstrand, P. An approach to produce nano-ligno-cellulose from mechanical pulp fine materials. Nord. Pulp Pap. Res. J. 2013, 28, 472-479. [CrossRef]

57. Lahtinen, P.; Liukkonen, S.; Pere, J.; Sneck, A.; Kangas, H. A Comparative Study of Fibrillated Fibers from Different Mechanical and Chemical Pulps. BioResources 2014, 9, 2115-2127. [CrossRef]

58. Rojo, E.; Peresin, M.S.; Sampson, W.W.; Hoeger, I.C.; Vartiainen, J.; Laine, J.; Rojas, O.J. Comprehensive elucidation of the effect of residual lignin on the physical, barrier, mechanical and surface properties of nanocellulose films. Green Chem. 2015, 17, 1853-1866. [CrossRef]

59. Santucci, B.S.; Bras, J.; Belgacem, M.N.; Curvelo, A.A.D.S.; Pimenta, M.T.B. Evaluation of the effects of chemical composition and refining treatments on the properties of nanofibrillated cellulose films from sugarcane bagasse. Ind. Crop. Prod. 2016, 91, 238-248. [CrossRef]

60. Correia, V.D.C.; dos Santos, V.; Sain, M.; Santos, S.F.; Leão, A.L.; Junior, H.S. Grinding process for the production of nanofibrillated cellulose based on unbleached and bleached bamboo organosolv pulp. Cellulose 2016, 23, 2971-2987. [CrossRef]

61. Liimatainen, H.; Visanko, M.; Sirviö, J.; Hormi, O.E.O.; Niinimaki, J. Enhancement of the Nanofibrillation of Wood Cellulose through Sequential Periodate-Chlorite Oxidation. Biomacromolecules 2012, 13, 1592-1597. [CrossRef]

62. Tripathi, A.; Ferrer, A.; Khan, S.A.; Rojas, O.J. Morphological and Thermochemical Changes upon Autohydrolysis and Microemulsion Treatments of Coir and Empty Fruit Bunch Residual Biomass to Isolate Lignin-Rich Micro- and Nanofibrillar Cellulose. ACS Sustain. Chem. Eng. 2017, 5, 2483-2492. [CrossRef]

63. Nie, S.; Zhang, K.; Lin, X.; Zhang, C.; Yan, D.; Liang, H.; Wang, S. Enzymatic pretreatment for the improvement of dispersion and film properties of cellulose nanofibrils. Carbohydr. Polym. 2018, 181, 1136-1142. [CrossRef] [PubMed]

64. Malucelli, L.C.; Matos, M.; Jordão, C.; Lomonaco, D.; Lacerda, L.G.; Filho, M.A.S.C.; Magalhaes, W. Influence of cellulose chemical pretreatment on energy consumption and viscosity of produced cellulose nanofibers (CNF) and mechanical properties of nanopaper. Cellulose 2018, 26, 1667-1681. [CrossRef]

65. Petroudy, S.R.D.; Rahmani, N.; Garmaroody, E.R.; Rudi, H.; Ramezani, O. Comparative study of cellulose and lignocellulose nanopapers prepared from hard wood pulps: Morphological, structural and barrier properties. Int. J. Biol. Macromol. 2019, 135, 512-520. [CrossRef] [PubMed]

66. Jiang, Y.; Liu, X.; Yang, Q.; Song, X.; Qin, C.; Wang, S.; Li, K. Effects of residual lignin on mechanical defibrillation process of cellulosic fiber for producing lignocellulose nanofibrils. Cellulose 2018, 25, 6479-6494. [CrossRef]

67. Dizhbite, T.; Telysheva, G.; Jurkjane, V.; Viesturs, U. Characterization of the radical scavenging activity of lignins-natural antioxidants. Bioresour. Technol. 2004, 95, 309-317. [CrossRef] [PubMed]

68. Shao, Z.; Li, K. The Effect of Fiber Surface Lignin on Interfiber Bonding. J. Wood Chem. Technol. 2006, 26, 231-244. [CrossRef]

69. Pääkkö, M.; Ankerfors, M.; Kosonen, H.; Nykänen, A.; Ahola, S.; Österberg, M.; Ruokolainen, J.; Laine, J.; Larsson, P.T.; Ikkala, O.; et al. Enzymatic Hydrolysis Combined with Mechanical Shearing and High-Pressure Homogenization for Nanoscale Cellulose Fibrils and Strong Gels. Biomacromolecules 2007, 8, 1934-1941. [CrossRef]

70. Espinosa, E.; Domínguez-Robles, J.; Sánchez, R.; Tarrés, Q.; Rodríguez, A. The effect of pre-treatment on the production of lignocellulosic nanofibers and their application as a reinforcing agent in paper. Cellulose 2017, 24, 2605-2618. [CrossRef] 
71. He, M.; Yang, G.; Chen, J.; Ji, X.; Wang, Q. Production and Characterization of Cellulose Nanofibrils from Different Chemical and Mechanical Pulps. J. Wood Chem. Technol. 2018, 38, 149-158. [CrossRef]

72. Kargarzadeh, H.; Ioelovich, M.; Ahmad, I.; Thomas, S.; Dufresne, A. Methods for Extraction of Nanocellulose from Various Sources. In Handbook of Nanocellulose and Cellulose Nanocomposites; John Wiley \& Sons, USA. John Wiley \& Sons: Hoboken, NJ, USA, 2017; pp. 1-49. [CrossRef]

73. Müller, R.; Jacobs, C.; Kayser, O. Nanosuspensions as particulate drug formulations in therapy: Rationale for development and what we can expect for the future. Adv. Drug Deliv. Rev. 2001, 47, 3-19. [CrossRef]

74. Kalia, S.; Boufi, S.; Celli, A.; Kango, S. Nanofibrillated cellulose: Surface modification and potential applications. Colloid Polym. Sci. 2014, 292, 5-31. [CrossRef]

75. Park, J.I.; Saffari, A.; Kumar, S.; Guenther, A.; Kumacheva, E. Microfluidic Synthesis of Polymer and Inorganic Particulate Materials. Annu. Rev. Mater. Res. 2010, 40, 415-443. [CrossRef]

76. De Moura, M.R.; Aouada, F.A.; De Azeredo, H.M.C.; Mattoso, L.H.C. Microfluidizer Technique for Improving Microfiber Properties Incorporated Into Edible and Biodegradable Films. Adv. Microfluid. 2012, 10, 219-240. [CrossRef]

77. Bai, L.; McClements, D.J. Formation and stabilization of nanoemulsions using biosurfactants: Rhamnolipids. J. Colloid Interface Sci. 2016, 479, 71-79. [CrossRef]

78. Otoni, C.G.; Carvalho, A.S.; Cardoso, M.; Bernardinelli, O.D.; Lorevice, M.V.; Colnago, L.A.; Loh, W.; Mattoso, L.H.C. HighPressure Microfluidization as a Green Tool for Optimizing the Mechanical Performance of All-Cellulose Composites. ACS Sustain. Chem. Eng. 2018, 6, 12727-12735. [CrossRef]

79. Solala, I.; Iglesias, M.C.; Peresin, M.S. On the potential of lignin-containing cellulose nanofibrils (LCNFs): A review on properties and applications. Cellulose 2019, 27, 1853-1877. [CrossRef]

80. Aulin, C.; Gällstedt, M.; Lindström, T. Oxygen and oil barrier properties of microfibrillated cellulose films and coatings. Cellulose 2010, 17, 559-574. [CrossRef]

81. Petroudy, S.R.D.; Ranjbar, J.; Garmaroody, E.R. Eco-friendly superabsorbent polymers based on carboxymethyl cellulose strengthened by TEMPO-mediated oxidation wheat straw cellulose nanofiber. Carbohydr. Polym. 2018, 197, 565-575. [CrossRef]

82. Ho, T.T.T.; Abe, K.; Zimmermann, T.; Yano, H. Nanofibrillation of pulp fibers by twin-screw extrusion. Cellulose 2014, 22, 421-433 [CrossRef]

83. Baati, R.; Magnin, A.; Boufi, S. High Solid Content Production of Nanofibrillar Cellulose via Continuous Extrusion. ACS Sustain. Chem. Eng. 2017, 5, 2350-2359. [CrossRef]

84. Rol, F.; Karakashov, B.; Nechyporchuk, O.; Terrien, M.; Meyer, V.; Dufresne, A.; Belgacem, M.N.; Bras, J. Pilot-Scale Twin Screw Extrusion and Chemical Pretreatment as an Energy-Efficient Method for the Production of Nanofibrillated Cellulose at High Solid Content. ACS Sustain. Chem. Eng. 2017, 5, 6524-6531. [CrossRef]

85. Rol, F.; Belgacem, M.N.; Gandini, A.; Bras, J. Recent advances in surface-modified cellulose nanofibrils. Prog. Polym. Sci. 2019, 88, 241-264. [CrossRef]

86. Perić, M.; Putz, R.; Paulik, C. Influence of nanofibrillated cellulose on the mechanical and thermal properties of poly(lactic acid). Eur. Polym. J. 2019, 114, 426-433. [CrossRef]

87. Rol, F.; Banvillet, G.; Meyer, V.; Petit-Conil, M.; Bras, J. Combination of twin-screw extruder and homogenizer to produce high-quality nanofibrillated cellulose with low energy consumption. J. Mater. Sci. 2018, 53, 12604-12615. [CrossRef]

88. Henriksson, M.; Berglund, L.; Lindström, T. An environmentally friendly method for enzyme-assisted preparation of microfibrillated cellulose (MFC) nanofibers. Eur. Polym. J. 2007, 43, 3434-3441. [CrossRef]

89. Hassan, E.A.; Hassan, M.L.; Oksman, K. Improving bagasse pulp paper sheet properties with microfibrillated cellulose isolated from xylanase-treated bagasse. Wood Fiber Sci. 2011, 43, 76-82.

90. Wang, W.; Mozuch, M.D.; Sabo, R.C.; Kersten, P.; Zhu, J.Y.; Jin, Y. Endoglucanase post-milling treatment for producing cellulose nanofibers from bleached eucalyptus fibers by a supermasscolloider. Cellulose 2016, 23, 1859-1870. [CrossRef]

91. Jeoh, T.; Cardona, M.J.; Karuna, N.; Mudinoor, A.R.; Nill, J. Mechanistic kinetic models of enzymatic cellulose hydrolysisA review. Biotechnol. Bioeng. 2017, 114, 1369-1385. [CrossRef]

92. French, A.D. Glucose, not cellobiose, is the repeating unit of cellulose and why that is important. Cellulose 2017, 24, 4605-4609. [CrossRef]

93. Yoo, S.; Hsieh, J.S. Enzyme-Assisted Preparation of Fibrillated Cellulose Fibers and Its Effect on Physical and Mechanical Properties of Paper Sheet Composites. Ind. Eng. Chem. Res. 2010, 49, 2161-2168. [CrossRef]

94. Zhu, J.Y.; Sabo, R.; Luo, X. Integrated production of nano-fibrillated cellulose and cellulosic biofuel (ethanol) by enzymatic fractionation of wood fibers. Green Chem. 2011, 13, 1339-1344. [CrossRef]

95. Tibolla, H.; Pelissari, F.M.; Menegalli, F.C. Cellulose nanofibers produced from banana peel by chemical and enzymatic treatment. LWT 2014, 59, 1311-1318. [CrossRef]

96. Delgado-Aguilar, M.; Tarrés, Q.; Puig, J.; Boufi, S.; Blanco, A.; Pujol, P.M. Enzymatic Refining and Cellulose Nanofiber Addition in Papermaking Processes from Recycled and Deinked Slurries. BioResources 2015, 10, 5730-5743. [CrossRef]

97. Martelli-Tosi, M.; Torricillas, M.D.S.; Martins, M.A.; De Assis, O.B.G.; Tapia-Blácido, D.R. Using Commercial Enzymes to Produce Cellulose Nanofibers from Soybean Straw. J. Nanomater. 2016, 2016, 1-10. [CrossRef]

98. Liu, X.; Jiang, Y.; Song, X.; Qin, C.; Wang, S.; Li, K. A bio-mechanical process for cellulose nanofiber production-Towards a greener and energy conservation solution. Carbohydr. Polym. 2019, 208, 191-199. [CrossRef] [PubMed] 
99. Wang, W.; Sabo, R.C.; Mozuch, M.D.; Kersten, P.; Zhu, J.Y.; Jin, Y. Physical and Mechanical Properties of Cellulose Nanofibril Films from Bleached Eucalyptus Pulp by Endoglucanase Treatment and Microfluidization. J. Polym. Environ. 2015, 23, 551-558. [CrossRef]

100. Wang, W.; Mozuch, M.D.; Sabo, R.C.; Kersten, P.; Zhu, J.Y.; Jin, Y. Production of cellulose nanofibrils from bleached eucalyptus fibers by hyperthermostable endoglucanase treatment and subsequent microfluidization. Cellulose 2015, 22, 351-361. [CrossRef]

101. Ankerfors, M. Microfibrillated Cellulose: Energy—Efficient Preparation Techniques and Applications in Paper. Ph.D. Thesis, KTH Royal Institute of Technology, Stockholm, Sweden, 2015.

102. Saito, T.; Okita, Y.; Nge, T.; Sugiyama, J.; Isogai, A. TEMPO-mediated oxidation of native cellulose: Microscopic analysis of fibrous fractions in the oxidized products. Carbohydr. Polym. 2006, 65, 435-440. [CrossRef]

103. Saito, T.; Kimura, S.; Nishiyama, Y.; Isogai, A. Cellulose Nanofibers Prepared by TEMPO-Mediated Ox. Biomacromolecules 2007, 8, 2485-2491. [CrossRef]

104. Saito, T.; Hirota, M.; Tamura, N.; Kimura, S.; Fukuzumi, H.; Heux, L.; Isogai, A. Individualization of Nano-Sized Plant Cellulose Fibrils by Direct Surface Carboxylation Using TEMPO Catalyst under Neutral Conditions. Biomacromolecules 2009, 10, 1992-1996. [CrossRef]

105. Fukuzumi, H.; Saito, T.; Iwata, T.; Kumamoto, Y.; Isogai, A. Transparent and High Gas Barrier Films of Cellulose Nanofibers Prepared by TEMPO-Mediated Oxidation. Biomacromolecules 2009, 10, 162-165. [CrossRef]

106. Saito, T.; Hirota, M.; Tamura, N.; Isogai, A. Oxidation of bleached wood pulp by TEMPO/NaClO/NaClO2 system: Effect of the oxidation conditions on carboxylate content and degree of polymerization. J. Wood Sci. 2010, 56, 227-232. [CrossRef]

107. Loranger, E.; Piché, A.-O.; Daneault, C. Influence of High Shear Dispersion on the Production of Cellulose Nanofibers by Ultrasound-Assisted TEMPO-Oxidation of Kraft Pulp. Nanomaterials 2012, 2, 286-297. [CrossRef] [PubMed]

108. Bates, I.I.C.; Carrillo, I.B.S.; Germain, H.; Loranger, É.; Chabot, B. Antibacterial electrospun chitosan-PEO/TEMPO-oxidized cellulose composite for water filtration. J. Environ. Chem. Eng. 2021, 9, 106204. [CrossRef]

109. Myja, D.; Loranger, E.; Lanouette, R. TEMPO Mediated Oxidation Optimization on Thermomechanical Pulp for Paper Reinforcement and Nanomaterial Film Production. BioResources 2018, 13, 4075-4092. [CrossRef]

110. Myja, D.; Loranger, E.; Lanouette, R. The effects of 4-acetamido-TEMPO-mediated oxidation on the extraction components of thermomechanical pulp. Cellulose 2019, 26, 5653-5663. [CrossRef]

111. De Nooy, A.E.; Besemer, A.C.; van Bekkum, H. Highly selective nitroxyl radical-mediated oxidation of primary alcohol groups in water-soluble glucans. Carbohydr. Res. 1995, 269, 89-98. [CrossRef]

112. Chang, P.S.; Robyt, J.F. Oxidation of Primary Alcohol Groups of Naturally Occurring Polysaccharides with 2,2,6,6-Tetramethyl-1Piperidine Oxoammonium Ion. J. Carbohydr. Chem. 1996, 15, 819-830. [CrossRef]

113. Biliuta, G.; Fras, L.; Strnad, S.; Harabagiu, V.; Coseri, S. Oxidation of cellulose fibers mediated by nonpersistent nitroxyl radicals. J. Polym. Sci. Part A Polym. Chem. 2010, 48, 4790-4799. [CrossRef]

114. Isogai, T.; Yanagisawa, M.; Isogai, A. Degrees of polymerization (DP) and DP distribution of cellouronic acids prepared from alkali-treated celluloses and ball-milled native celluloses by TEMPO-mediated oxidation. Cellulose 2008, 16, 117-127. [CrossRef]

115. Isogai, A. Review Development of completely dispersed cellulose nano fi bers. Proc. Jpn. Acad. Ser. B 2018, 94, 161-179. [CrossRef]

116. Kuramae, R.; Saito, T.; Isogai, A. TEMPO-oxidized cellulose nanofibrils prepared from various plant holocelluloses. React. Funct. Polym. 2014, 85, 126-133. [CrossRef]

117. Alila, S.; Besbes, I.; Vilar, M.R.; Mutjé, P.; Boufi, S. Non-woody plants as raw materials for production of microfibrillated cellulose (MFC): A comparative study. Ind. Crop. Prod. 2013, 41, 250-259. [CrossRef]

118. Tarrés, Q.; Boufi, S.; Mutjé, P.; Delgado-Aguilar, M. Enzymatically hydrolyzed and TEMPO-oxidized cellulose nanofibers for the production of nanopapers: Morphological, optical, thermal and mechanical properties. Cellulose 2017, 24, 3943-3954. [CrossRef]

119. Puangsin, B.; Fujisawa, S.; Kuramae, R.; Saito, T.; Isogai, A. TEMPO-Mediated Oxidation of Hemp Bast Holocellulose to Prepare Cellulose Nanofibrils Dispersed in Water. J. Polym. Environ. 2012, 21, 555-563. [CrossRef]

120. Okita, Y.; Saito, T.; Isogai, A. Entire Surface Oxidation of Various Cellulose Microfibrils by TEMPO-Mediated Oxidation. Biomacromolecules 2010, 11, 1696-1700. [CrossRef] [PubMed]

121. Wågberg, L.; Decher, G.; Norgren, M.; Lindström, T.; Ankerfors, M.; Axnäs, K. The Build-Up of Polyelectrolyte Multilayers of Microfibrillated.pdf. PEMs of MFC and Cationic Polyelectrolytes oxide. Langmuir 2008, 24, 784-795. [CrossRef]

122. Ahola, S.; Salmi, J.; Johansson, L.-S.; Laine, J.; Österberg, M. Model Films from Native Cellulose Nanofibrils. Preparation, Swelling, and Surface Interactions. Biomacromolecules 2008, 9, 1273-1282. [CrossRef]

123. Eyholzer, C.; Bordeanu, N.; Lopez-Suevos, F.; Rentsch, D.; Zimmermann, T.; Oksman, K. Preparation and characterization of water-redispersible nanofibrillated cellulose in powder form. Cellulose 2010, 17, 19-30. [CrossRef]

124. Taipale, T.; Österberg, M.; Nykänen, A.; Ruokolainen, J.; Laine, J. Effect of microfibrillated cellulose and fines on the drainage of kraft pulp suspension and paper strength. Cellulose 2010, 17, 1005-1020. [CrossRef]

125. Arvidsson, R.; Nguyen, D.; Svanström, M. Life Cycle Assessment of Cellulose Nanofibrils Production by Mechanical Treatment and Two Different Pretreatment Processes. Environ. Sci. Technol. 2015, 49, 6881-6890. [CrossRef]

126. Onyianta, A.J.; Dorris, M.; Williams, R.L. Aqueous morpholine pre-treatment in cellulose nanofibril (CNF) production: Comparison with carboxymethylation and TEMPO oxidisation pre-treatment methods. Cellulose 2018, 25, 1047-1064. [CrossRef]

127. Laine, J.; Lindstrom, T.; Brernberg, C.; Glad-Nordrnark, G. Studies on topochemical modification of cellulosic fibres. Nord. Pulp Pap. Res. J. 2003, 18, 316-324. [CrossRef] 
128. Horvath, A.E.; Lindström, T.; Laine, J. On the Indirect Polyelectrolyte Titration of Cellulosic Fibers. Conditions for Charge Stoichiometry and Comparison with ESCA. Langmuir 2006, 22, 824-830. [CrossRef] [PubMed]

129. Duker, E.; Ankerfors, M.; Lindström, T.; Nordmark, G.G. The use of CMC as a dry strength agent-The interplay between CMC attachment and drying. Nord. Pulp Pap. Res. J. 2008, 23, 65-71. [CrossRef]

130. Wågberg, L.; Winter, L.; Ödberg, L.; Lindström, T. On the charge stoichiometry upon adsorption of a cationic polyelectrolyte on cellulosic materials. Colloids Surfaces 1987, 27, 163-173. [CrossRef]

131. Naderi, A.; Lindström, T.; Sundström, J.; Flodberg, G.; Erlandsson, J. A comparative study of the properties of three nanofibrillated cellulose systems that have been produced at about the same energy consumption levels in the mechanical delamination step. Nord. Pulp Pap. Res. J. 2016, 31, 364-371. [CrossRef]

132. Sirviö, J.; Hyvakko, U.; Liimatainen, H.; Niinimaki, J.; Hormi, O. Periodate oxidation of cellulose at elevated temperatures using metal salts as cellulose activators. Carbohydr. Polym. 2011, 83, 1293-1297. [CrossRef]

133. Kekäläinen, K.; Liimatainen, H.; Niinimäki, J. Disintegration of periodate-chlorite oxidized hardwood pulp fibres to cellulose microfibrils: Kinetics and charge threshold. Cellulose 2014, 21, 3691-3700. [CrossRef]

134. Chinga-Carrasco, G.; Syverud, K. Pretreatment-dependent surface chemistry of wood nanocellulose for pH-sensitive hydrogels. J. Biomater. Appl. 2014, 29, 423-432. [CrossRef] [PubMed]

135. Yang, H.; Chen, D.; Van De Ven, T.G.M. Preparation and characterization of sterically stabilized nanocrystalline cellulose obtained by periodate oxidation of cellulose fibers. Cellulose 2015, 22, 1743-1752. [CrossRef]

136. Errokh, A.; Magnin, A.; Putaux, J.-L.; Boufi, S. Morphology of the nanocellulose produced by periodate oxidation and reductive treatment of cellulose fibers. Cellulose 2018, 25, 3899-3911. [CrossRef]

137. Hou, Q.X.; Liu, W.; Liu, Z.H.; Bai, L.L. Characteristics of Wood Cellulose Fibers Treated with Periodate and Bisulfite. Ind. Eng. Chem. Res. 2007, 46, 7830-7837. [CrossRef]

138. Rajalaxmi, D.; Jiang, N.; Leslie, G.; Ragauskas, A.J. Synthesis of novel water-soluble sulfonated cellulose. Carbohydr. Res. 2010, 345, 284-290. [CrossRef]

139. Liimatainen, H.; Visanko, M.; Sirvio, J.A.; Hormi, O.; Niinimäki, J. Sulfonated cellulose nanofibrils obtained from wood pulp through regioselective oxidative bisulfite pre-treatment. Cellulose 2013, 20, 741-749. [CrossRef]

140. Larsson, P.A.; Berglund, L.A.; Wågberg, L. Highly ductile fibres and sheets by core-shell structuring of the cellulose nanofibrils. Cellulose 2014, 21, 323-333. [CrossRef]

141. Larsson, P.A.; Berglund, L.; Wågberg, L. Ductile All-Cellulose Nanocomposite Films Fabricated from Core-Shell Structured Cellulose Nanofibrils. Biomacromolecules 2014, 15, 2218-2223. [CrossRef]

142. Naderi, A.; Koschella, A.; Heinze, T.; Shih, K.-C.; Nieh, M.-P.; Pfeifer, A.; Chang, C.-C.; Erlandsson, J. Sulfoethylated nanofibrillated cellulose: Production and properties. Carbohydr. Polym. 2017, 169, 515-523. [CrossRef]

143. Ablouh, E.-H.; Brouillette, F.; Taourirte, M.; Sehaqui, H.; El Achaby, M.; Belfkira, A. A highly efficient chemical approach to producing green phosphorylated cellulosic macromolecules. RSC Adv. 2021, 11, 24206-24216. [CrossRef]

144. Shi, Y.; Belosinschi, D.; Brouillette, F.; Belfkira, A.; Chabot, B. Phosphorylation of Kraft fibers with phosphate esters. Carbohydr. Polym. 2014, 106, 121-127. [CrossRef]

145. Ghanadpour, M.; Carosio, F.; Larsson, P.T.; Wågberg, L. Phosphorylated Cellulose Nanofibrils: A Renewable Nanomaterial for the Preparation of Intrinsically Flame-Retardant Materials. Biomacromolecules 2015, 16, 3399-3410. [CrossRef] [PubMed]

146. Noguchi, Y.; Homma, I.; Matsubara, Y. Complete nanofibrillation of cellulose prepared by phosphorylation. Cellulose 2017, 24, 1295-1305. [CrossRef]

147. Zhang, Q.; Vigier, K.D.O.; Royer, S.; Jerome, F. Deep eutectic solvents: Syntheses, properties and applications. Chem. Soc. Rev. 2012, 41, 7108-7146. [CrossRef] [PubMed]

148. Cui, Q.; Liu, J.-Z.; Wang, L.-T.; Kang, Y.-F.; Meng, Y.; Jiao, J.; Fu, Y.-J. Sustainable deep eutectic solvents preparation and their efficiency in extraction and enrichment of main bioactive flavonoids from sea buckthorn leaves. J. Clean. Prod. 2018, 184, 826-835. [CrossRef]

149. Li, P.; Sirviö, J.A.; Haapala, A.; Liimatainen, H. Cellulose Nanofibrils from Nonderivatizing Urea-Based Deep Eutectic Solvent Pretreatments. ACS Appl. Mater. Interfaces 2017, 9, 2846-2855. [CrossRef]

150. Abbott, A.P.; Bell, T.J.; Handa, S.; Stoddart, B. Cationic functionalisation of cellulose using a choline based ionic liquid analogue. Green Chem. 2006, 8, 784-786. [CrossRef]

151. Suopajärvi, T.; Sirviö, J.A.; Liimatainen, H. Nanofibrillation of deep eutectic solvent-treated paper and board cellulose pulps. Carbohydr. Polym. 2017, 169, 167-175. [CrossRef] [PubMed]

152. Tenhunen, T.-M.; Lewandowska, A.E.; Orelma, H.; Johansson, L.-S.; Virtanen, T.; Harlin, A.; Österberg, M.; Eichhorn, S.J.; Tammelin, T. Understanding the interactions of cellulose fibres and deep eutectic solvent of choline chloride and urea. Cellulose 2017, 25, 137-150. [CrossRef]

153. Sirviö, J.A.; Visanko, M.; Liimatainen, H. Deep eutectic solvent system based on choline chloride-urea as a pre-treatment for nanofibrillation of wood cellulose. Green Chem. 2015, 17, 3401-3406. [CrossRef]

154. Selkälä, T.; Sirviö, J.A.; Lorite, G.S.; Liimatainen, H. Anionically Stabilized Cellulose Nanofibrils through Succinylation Pretreatment in Urea-Lithium Chloride Deep Eutectic Solvent. ChemSusChem 2016, 9, 3074-3083. [CrossRef] [PubMed]

155. Tabar, I.B.; Zhang, X.; Youngblood, J.P.; Mosier, N.S. Production of cellulose nanofibers using phenolic enhanced surface oxidation. Carbohydr. Polym. 2017, 174, 120-127. [CrossRef] [PubMed] 
156. Hellström, P.; Heijnesson-Hultén, A.; Paulsson, M.; Håkansson, H.; Germgård, U. The effect of Fenton chemistry on the properties of microfibrillated cellulose. Cellulose 2014, 21, 1489-1503. [CrossRef]

157. Ruan, C.-Q.; Gustafsson, S.; Strømme, M.; Mihranyan, A.; Lindh, J. Cellulose Nanofibers Prepared via Pretreatment Based on Oxone ${ }^{\circledR O x i d a t i o n . ~ M o l e c u l e s ~ 2017, ~ 22, ~ 2177 . ~[C r o s s R e f] ~}$

158. Ruan, C.-Q.; Strømme, M.; Mihranyan, A.; Lindh, J. Favored surface-limited oxidation of cellulose with Oxone®in water. RSC Adv. 2017, 7, 40600-40607. [CrossRef]

159. Kachkarova-Sorokina, S.L.; Gallezot, P.; Sorokin, A.B. A novel clean catalytic method for waste-free modification of polysaccharides by oxidation. Chem. Commun. 2004, 2844-2845. [CrossRef] [PubMed]

160. Carlsson, D.O.; Lindh, J.; Nyholm, L.; Strømme, M.; Mihranyan, A. Cooxidant-free TEMPO-mediated oxidation of highly crystalline nanocellulose in water. RSC Adv. 2014, 4, 52289-52298. [CrossRef] 